\title{
QUEEN'S
UNIVERSITY
BELFAST
}

\section{Urogynecological surgical mesh implants: new trends in materials, manufacturing and therapeutic approaches}

Farmer, Z-L., Dominguez Robles, J., Mancinelli, C., Larrañeta, E., \& Lamprou, D. (Accepted/In press).

Urogynecological surgical mesh implants: new trends in materials, manufacturing and therapeutic approaches. International Journal of Pharmaceutics.

Published in:

International Journal of Pharmaceutics

Document Version:

Peer reviewed version

Queen's University Belfast - Research Portal:

Link to publication record in Queen's University Belfast Research Portal

Publisher rights

Copyright 2020 Elsevier.

This manuscript is distributed under a Creative Commons Attribution-NonCommercial-NoDerivs License

(https://creativecommons.org/licenses/by-nc-nd/4.0/), which permits distribution and reproduction for non-commercial purposes, provided the author and source are cited.

\section{General rights}

Copyright for the publications made accessible via the Queen's University Belfast Research Portal is retained by the author(s) and / or other copyright owners and it is a condition of accessing these publications that users recognise and abide by the legal requirements associated with these rights.

Take down policy

The Research Portal is Queen's institutional repository that provides access to Queen's research output. Every effort has been made to ensure that content in the Research Portal does not infringe any person's rights, or applicable UK laws. If you discover content in the Research Portal that you believe breaches copyright or violates any law, please contact openaccess@qub.ac.uk. 


\title{
Urogynecological surgical mesh implants: new trends in
}

\section{materials, manufacturing and therapeutic approaches}

\author{
Zara-Louise Farmer ${ }^{1+}$, Juan Domínguez-Robles ${ }^{1 \dagger}$, Caterina Mancinelli $^{1}$, Eneko Larrañeta ${ }^{{ }^{*}}$, \\ Dimitrios A. Lamprou ${ }^{*}$
}

${ }^{1}$ School of Pharmacy, Queen's University Belfast, 97 Lisburn Road, Belfast BT9 7BL, UK.

*Correspondence: d.lamprou@qub.ac.uk \& e.larraneta@qub.ac.uk; Tel.: +44-28-9097-2617.

+ These authors contributed equally to this work.

Abstract: Pelvic Organ Prolapse (POP) and Stress Urinary Incontinence (SUI) are two prevalent disorders affecting 30-40\% of women worldwide. Current strategies to repair or improve these medical conditions are non-surgical options such as physiotherapy, or surgical options such as the use of vaginal meshes. The synthetic material polypropylene (PP), which has long been used for manufacturing these vaginal meshes, is associated with severe complications such as chronic pain, infection or mesh erosion. As a result of a widespread reporting and unacceptably high rates of complications, these issues have become a public health concern. Regulatory bodies have recently deemed the transvaginal placement of PP mesh in the pelvic floor $(\mathrm{PF})$ no longer a suitable treatment method for PF repair, leading to the need for a novel approach to the manufacture and selection of materials for urogynecological meshes. Medical devices, such as vaginal meshes can be manufactured using a variety of techniques including injection moulding, electrospinning, hot-melt extrusion (HME) or more recently 3D printing. Over the past decade, the use of 3D printing within the medical device industry has expanded and offers a promising approach to manufacture patient-specific surgical mesh when combined with imaging tools. This review will summarise the current strategies to treat POP and SUI, the issues and use of current meshes for the treatment of these pelvic floor disorders (PFDs), and the future directions for the manufacture of more suitable urogynecological meshes, as well as their potential materials. 
Keywords: Pelvic organ prolapse; stress urinary incontinence; surgical mesh; extrusion; electrospinning; implants; 3D printing.

\section{Introduction}

Pelvic floor disorders (PFDs), including pelvic organ prolapse (POP) and stress urinary incontinence (SUI), affect women worldwide, particularly those over the age of 40, and are a significant source of morbidity (Abdel-Fattah et al., 2011; Mironska et al., 2019). Although the true prevalence of these conditions is difficult to determine, it is estimated that one in three and one in nine women are affected by SUI and POP, respectively (Loganathan et al., 2019). While these disorders are not life-threatening, they reduce the quality of life for women due to the negative impact inflicted upon their social, physical and psychological wellbeing (Abdel-Fattah et al., 2011). Up to 20\% of these women will undergo at least one surgical procedure for SUI or POP during their lifetime, creating substantial cost implications for healthcare systems (Dieter et al., 2015). The United Kingdom (UK) National Health Service (NHS) spends approximately $£ 233 \mathrm{M}$ on urinary incontinence treatment annually, and over $£ 45 \mathrm{M}$ was spent on POP treatment between 2017-2018 in England alone (Loganathan et al., 2019; Primary Care Women's Health Forum, 2019). Although healthcare costs for urinary incontinence vary among countries, the total expenditure, both direct and indirect, in Europe is nearly $€ 10 \mathrm{~b}$, with the majority spent on SUI (Zwolsman et al., 2019). Furthermore, an excess of $\$ 1 b$ is spent annually on the treatment of PFDs in the United States of America (USA), and it is forecast that by 2050 the ageing population will increase the incidence of SUI by $55 \%$ and POP by $46 \%$, exacerbating the burden on healthcare resources and the economy (Wu et al., 2009).

\subsection{Female pelvic anatomy}

The pelvic floor (PF) is composed of ligaments, muscles and connective tissue, providing support to the overlaying pelvic organs including the bladder, rectum and uterus. POP results from the weakening of these supports, causing descent of the pelvic organs from their natural positions (Fig. 1A). A cystocele (Fig. 1B) is the most common type of prolapse followed by a uterine prolapse (Fig. 1C), a rectocele (Fig. 1D) and a vault prolapse (Fig. 1E) 
48

49

50

51

52

53
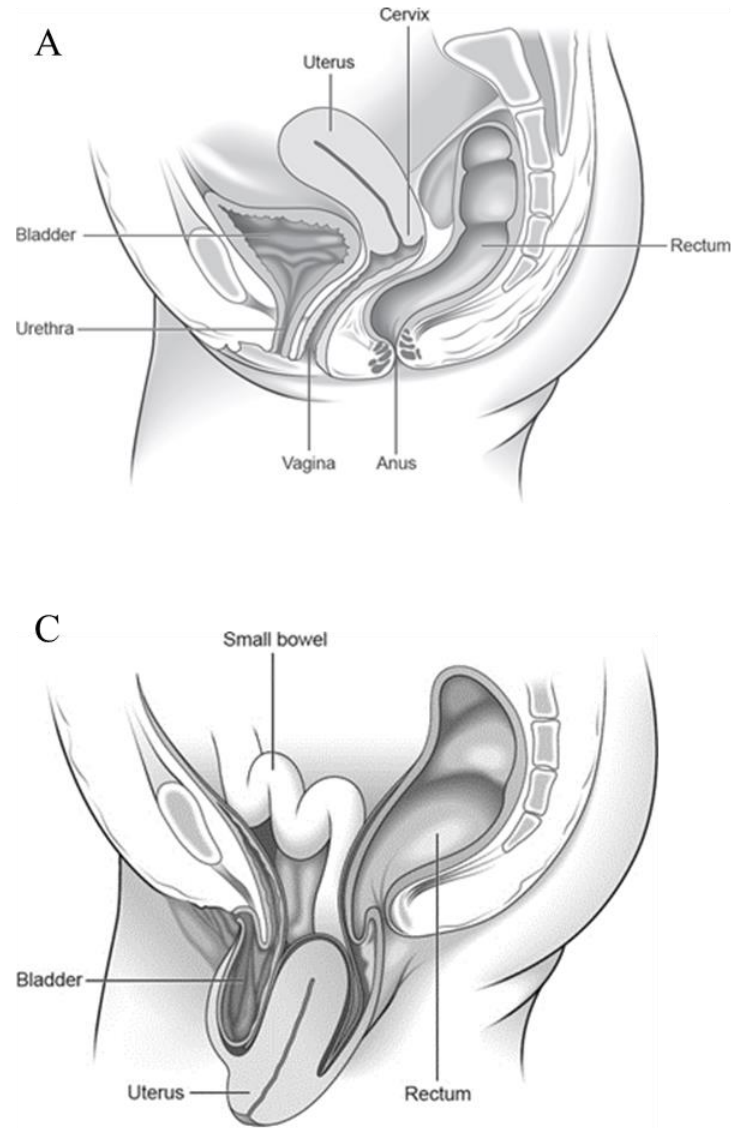

B

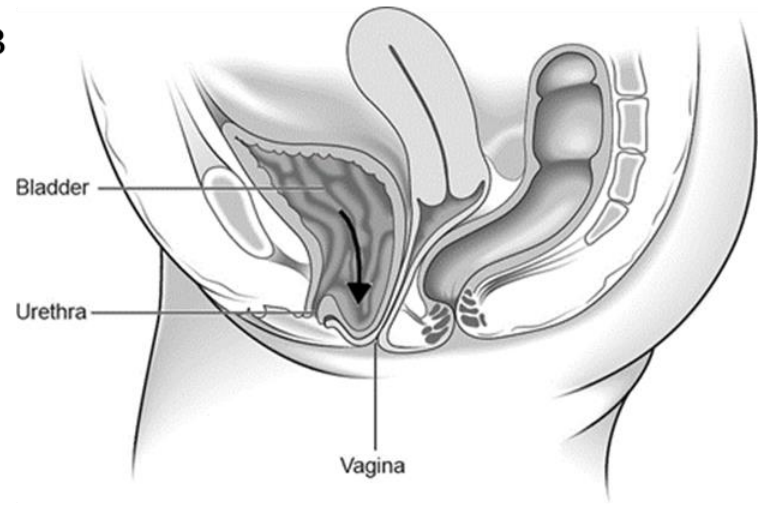

D

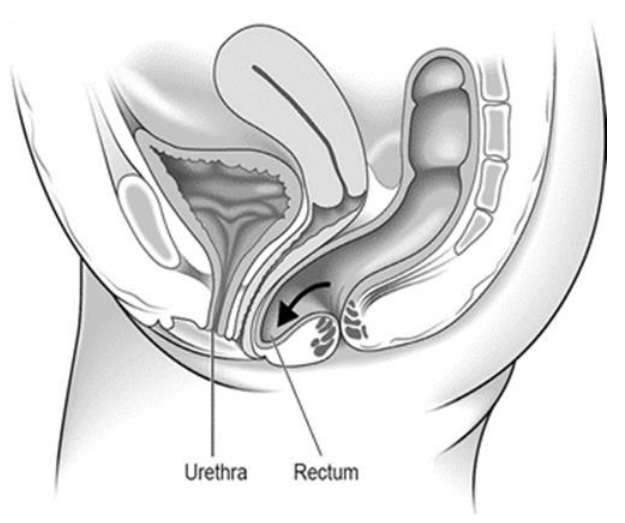

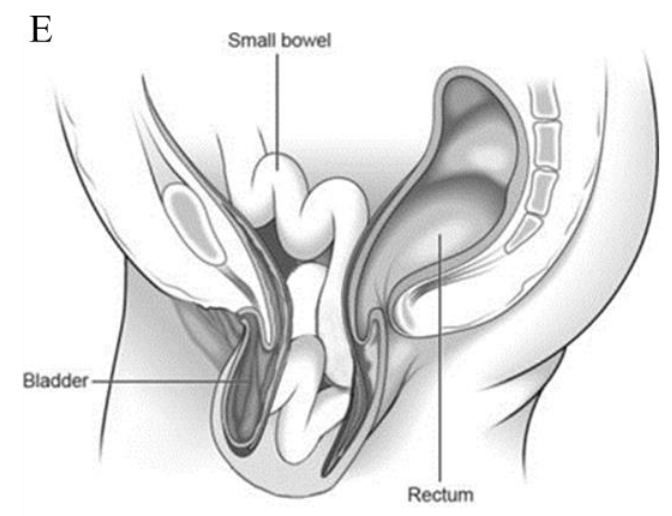

55 Fig. 1. Normal female pelvic anatomy (A), Cystocele (B), Uterine prolapse (C), Rectocele (D), and Vault prolapse (E) (Royal College of Obstetricians and Gynaecologists, 2013). 
Parous women are particularly at risk of developing POP due to the strain, which pregnancy and childbirth place on the PF, stretching and potentially tearing the PF muscles and connective tissue (U.S. Food and Drug Administration, 2019a). Postmenopausal women are also likely to develop POP due to the decline in oestrogen production after menopause (Tso et al., 2018). Oestrogen receptors control the synthesis and breakdown of collagen, the main structural protein found in connective tissue. Reduced levels of oestrogen may weaken the support provided by the PF and cause thinning of the vaginal epithelium, potentially contributing to POP susceptibility (Weber et al., 2015). Furthermore, muscle atrophy occurs as women age, degenerating and weakening the supporting muscles of the pelvic organs (Tso et al., 2018).

In up to $80 \%$ of women with PF dysfunction, POP will coexist with SUI due to the related pathophysiology of these conditions (Loganathan et al., 2019). SUI is the involuntary leakage of urine when pressure is exerted on the abdomen, for instance, when exercising, coughing or sneezing. Similar to POP, SUI results from weakening of the PF ligaments, muscles and connective tissue, which normally support the bladder neck and urethra (Fig. 2). Without this support, the bladder neck is able to descend when abdominal pressure increases, hindering the control of urine flow provided by the urethra. SUI may also result from weakening of the sphincter muscles, which control the urethra (Fig. 2). Similar to POP, weakening of these supports is multifactorial and primarily attributable to pregnancy, menopause or ageing (U.S. Food and Drug Administration, 2019b). Several other risk factors, including obesity, previous pelvic reconstructive surgery and connective tissue disorders may contribute to both SUI and POP susceptibility (Mironska et al., 2019). 


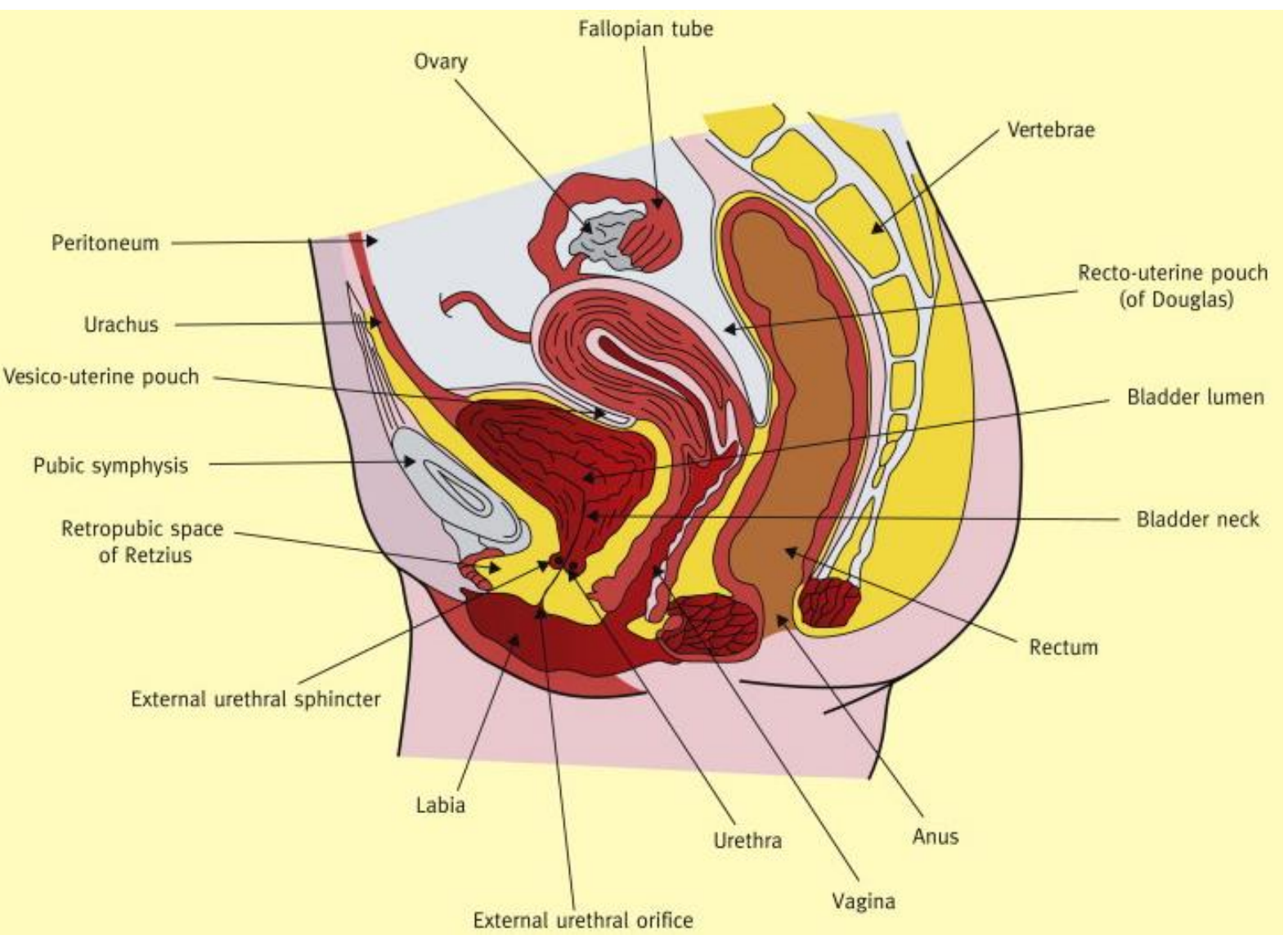

Fig. 2. Urinary bladder control system. Reproduced with permission from the cited reference (Mangera et al., 2013).

\section{Current treatment for SUI and POP}

According to clinical guidelines, including those stipulated by the UK National 84 Institute for Health and Care Excellence (NICE) and the European Association of Urology (EAU), pelvic floor muscle training (PFMT) should be the initial treatment method offered to patients presenting with SUI or mild-to-moderate POP (Loganathan et al., 2019). PFMT is a non-surgical treatment method that aims to strengthen the muscles of the PF with repeated muscle contractions. Adverse events associated with PFMT are uncommon, and it has been demonstrated to achieve some improvements in POP and SUI symptoms. However, research regarding the long-term efficacy of PFMT is still in progress. When conservative treatment

91 fails to improve the symptoms of POP and SUI, or the prolapse is at an advanced stage, 92 surgical intervention is necessary to limit interference with the patients daily life (Wu and 93 Welk, 2019). 
In the past, surgical treatment for POP was limited to the use of sutures for repair of the patient's native tissue, aiming to strengthen the PF and provide additional support to the prolapsed pelvic organs (Mironska et al., 2019). For SUI treatment, McGuire and Lytton popularised the use of an autologous fascial pubovaginal sling (PVS) in 1978; this technique used rectus fascia or fascia lata graft slings to support the urethra (Bang and Belal, 2016). However, the support provided by native tissue repair was inadequate, with failure rates between $17-20 \%$ ten years after surgery, generating high rates of recurrence and reoperation for prolapse. Consequently, attention shifted to the use of surgical mesh to provide a stronger repair of the PF (Mironska et al., 2019).

Surgical mesh implants, mainly made from a sterile woven material which can be formed by monofilament threads or multifilament yarns and have non-absorbable or absorbable properties, are now frequently used for POP and SUI repair. A mesh implant has two main functions: firstly, to reinforce soft tissue defects, and secondly to support prolapsed organs and viscera.

Following the introduction of Mersilene ${ }^{\circledR}$ Mesh (Darcon $\left.{ }^{\circledR}\right)$ in the 1950s for abdominal hernia repair, gynaecologists began to implant hernia-indicated meshes through abdominal incisions for POP repair in the 1970s. As surgical techniques evolved, these meshes began to be implanted via the transvaginal route for POP repair during the 1990s (Macleod and Chakraborty, 2019; Soler et al., 2001). Medical device manufacturers in the US responded to this gap in the market by developing surgical meshes purposely designed for repairing POP and SUI. Boston Scientific's ProteGen Sling (a woven polyester sling with pressure injected bovine collagen) was the first mesh product to be purposely designed for surgical treatment of SUI, receiving approval from the US Food and Drug Administration (FDA) in 1996 (Soler et al., 2001). Since then, the use of synthetic mid-urethral slings (MUS) has superseded the conventional approach of using an autologous PVS and is now the most frequently used surgical procedure for female SUI treatment in Europe (Bang and Belal, 2016). Implantation of the MUS can be performed using either a retropubic or transobturator approach, with the implanted sling providing support to the urethra, correcting urinary incontinence (U.S. Food and Drug Administration, 2019b). Furthermore, in 2002 the FDA approved Gynemesh ${ }^{\circledR}$ PS, 
which was the first pre-configured transvaginal mesh for surgical repair of POP (U.S. Food and Drug Administration, 2018). Using synthetic mesh to augment the conventional approach of sutures provides additional support to the PF, preventing recurrent prolapse of the overlaying organs (Mironska et al., 2019).

\subsection{Mesh complications}

The use of polypropylene (PP) mesh for urogynecological surgery quickly became popular, with a surge of these medical devices coming to the market prior to the availability of full clinical trial data. The FDA 510(k) premarket approval process enabled these surgical meshes to gain access to the medical device market on the basis that they were equivalent to a legally marketed product, exempting them from clinical trial studies. For urogynecological mesh, this product was the ProteGen Sling, which in turn used the Mersilene ${ }^{\circledR}$ mesh as its predicate; however, Mersilene ${ }^{\circledR}$ mesh was designed for abdominal hernia repair, and the premarket approval process did not require testing of the safety and efficacy of this mesh in the PF (Mironska et al., 2019).

The implantation of PP mesh for POP and SUI repair was an acceptable practice prior to the FDA releasing two public health warnings in 2008 and 2011, which were followed by the release of statements from the UK Medicines and Healthcare products Regulatory Agency (MHRA). These warnings were the result of widespread reports regarding complications associated with the transvaginal implantation of PP mesh in the PF (Mangir et al., 2018). Women worldwide were, and currently still are, experiencing adverse effects such as chronic pain, mesh-related infection, inflammatory reactions and mesh erosion. Although mesh-related infections are relatively uncommon, when they do occur, they have the potential to compromise the patients' health and can even lead to excision of the mesh implant or sepsis (Mangir et al., 2019b).

In Europe and the US, mesh manufacturers are facing huge lawsuits, with many stopping the production of urogynecological mesh products. Many patients have begun to seek compensation, and although the exact quantification of litigation costs in the US is difficult to determine, the global pharmaceutical company Endo International Plc has 
reserved $\$ 2.6 b$ to deal with mesh lawsuits (Mironska et al., 2019). In the UK, approximately 800 compensation claims have arose against the NHS regarding mesh-related complications (Mangir et al., 2018). The NHS England put an immediate stop to mesh procedures in accordance with NICE guidelines, which strongly recommend that transvaginal mesh should not be used for POP repair, indicating the need for alternative treatment options to improve PFDs repair (BBC News, 2018a; Wise, 2017). The Australian Health Minister Greg Hunt issued a statement in 2018 apologising to all women suffering from mesh complications, further iterating the global impact of transvaginal mesh complications (BBC News, 2018b).

Transvaginal mesh products were reclassified from moderate-risk class II devices to high-risk class III devices in 2016, meaning the 510(k) process can no longer be used for mesh products to gain market access. A sharp decline from $27 \%$ to $2 \%$ has been observed in the use of transvaginal mesh for POP repair surgery, and the number of SUI surgeries using mesh sling has decreased as a knock-on effect (Mangir et al., 2018). Exactly 20 years after the first notification, on April 16, 2019, once confirming the high level of risks with respect to the benefits, the FDA ordered a stop to the production and sale of surgical meshes intended for transvaginal repair of anterior prolapse (cystocele) (U.S. Food and Drug Administration, n.d.). Given the widespread complications reported in the media and literature, it is evident that new mesh products will need to be developed with careful consideration of the mechanical and biological properties of the female PF, undergoing intense regulatory scrutiny (Mangir et al., 2018). Recent developments in areas such as biomaterials, tissue engineering and 3D printing, herald the promise to develop patient-specific, lifelong solutions for health problems.

\subsection{Drug eluting urogynecological meshes}

Some of the previously described complications reported after the implantation of vaginal meshes are infections and inflammation (Dias et al., 2015). Unlike problems related with mesh erosion, these issues can be treated/prevented using certain drugs (Dias et al., 2015). 

period to prevent mesh infection and biofilm formation (Andy et al., 2014). For pelvic surgery oral antibiotics such as metronidazole (500 mg twice a day) are commonly prescribed for prophylactic treatment (Lachiewicz et al., 2015). Alternatively, the antibiotic treatment can be administered during surgery or recovery within hospital (Andy et al., 2014). An alternative to these approaches is to load the antibiotic/antimicrobial molecule into the surgical mesh (Dias et al., 2015). In this way the mesh can provide a sustained release of antibiotic around the surgical site to prevent bacterial colonisation and biofilm formation (Dias et al., 2015). This approach has multiple advantages over the prophylactic approach as it requires lower doses of drug to be administered in the potential infection site (Campoccia et al., 2010). Accordingly, this strategy bypass or reduces the potential side effects associated with systemic antibiotic administration (Campoccia et al., 2010). Finally, antibiotic loaded biomaterials are less likely to promote antibiotic resistance ( $\mathrm{Wu}$ and Grainger, 2006).

In order to load the antibiotics into surgical meshes the most used approach is to coat 192 the biomaterials with a formulation containing antibiotics (Dias et al., 2015). This approach 193 has been extensively explored for other types of medical devices such as catheters (Essyrose 194 Mathew et al., 2019a). However, there are other valid strategies to incorporate the antibiotic molecule into the mesh including combining the antibiotic with the polymer in solution or trough hot-melt extrusion (HME) before forming the meshes (Juan Domínguez-Robles et al., 2020; Hall Barrientos et al., 2017a). The strategies followed to load antibiotics into vaginal meshes and the manufacturing techniques will be discussed in depth in section 4 of the current review article.

Despite all of the potential advantages of this strategy, the majority of the studies are pre-clinical studies. These studies are focused on biomaterial delivery and in some cases have demonstrated the material efficacy in animal models. An alternative to antibiotic loaded biomaterials to prevent infection is to use silver coatings (Dias et al., 2015). The antimicrobial potential of silver loaded into PP surgical meshes has been explored before with promising results (Badiou et al., 2011). However, this study was a preclinical study that used animal models and the efficacy of silver-coated meshes was not tested in human patients. 
An alternative cargo to antibacterial agents with potential to be incorporated into vaginal meshes are corticosteroids (Dias et al., 2015). The administration of perioperative corticosteroids is a common practice (Groleau et al., 2018). These compounds have antiinflammatory and immune-modulating properties (Chilkoti et al., 2019). They contribute to reduce foreign bodies inflammatory response locally (Brandt et al., 2011). This inflammatory reaction is associated with serious complications such as wound infection and chronic pain among others (Brandt et al., 2011). Previous reports suggest that meshes coated with corticosteroids (hydrocortisone/spironolactone) contributed to attenuate local inflammatory response to foreign bodies in an animal model (Brandt et al., 2011). Again, these promising results need to be tested in human patients before extracting further conclusions.

\section{Suitable materials for urogynecological surgical meshes}

The female PF undergoes significant movement, meaning a medical device that is to be placed in this area of the body, must possess elasticity and flexibility to withstand the stressors of this environment. Material choice is therefore of utmost importance since the mesh should not deform to an extent that would compromise its support, nor be so rigid that it would erode through the patient's tissues (Mironska et al., 2019). For instance, PP has been used to manufacture commercially available meshes such as ProteGen sling (Boston Scientific, Marlborough, Massachusetts, USA); Gynemesh® PS (Ethicon/Gyncare, Somerville, New Jersey, USA); Gynecare ${ }^{\mathrm{TM}}$ (Johnson \& Johnson) or knitted Restorelle ${ }^{\circledR}$ (Coloplast, Humlebaek, Denmark) with the aim of treating PFDs. However, although PP is still regarded as being stable for long-term use, this thermoplastic polymer showed a high bending stiffness when used for surgical mesh fabrication, resulting in relatively stiff mesh prostheses (Klinge et al., 2002). Moreover, recent research has shown that PP mesh triggers an inflammatory response in the host tissue when implanted in the PF, which is attributable to triggering of the pro-inflammatory M1 macrophages, rather than the M2 macrophages that result in constructive tissue remodelling (Mangir et al., 2019b). As this material is not ideal for the manufacture of surgical meshes due to the reasons explained above, alternative materials should be considered and examined. 
PVDF is a highly non-reactive thermoplastic fluorocarbon polymer produced by the polymerisation of vinylidene difluoride (Fig. 3). Furthermore, PVDF and its copolymers are 238 biocompatible and non-biodegradable, making them ideal for pharmaceutical and 239 biomedical applications, such as tissue engineering, where a long-term structural support is 240 required (Lee et al., 2011; Tandon et al., 2018). Additionally, PVDF is commonly used to manufacture pipes and fittings (Ezrin, 2013), valves (Ayyaru et al., 2020), cathodes \& anodes in Li-ion cell (Domínguez-Robles et al., 2017) or high purity semiconductor applications (Hu et al., 2020), among others. PVDF has already been used in the manufacturing of surgical meshes for hernia repair (Klinge et al., 2002) or for treating PFDs such as POP (Balsamo et al., 2018; Barski et al., 2017), which are available on the market under the name DynaMesh®. Although small works have shown that PVDF has better biocompatibility, reduced bacterial adherence, and more durable tensile properties than PP; in the long run these excellent results are missing (Balsamo et al., 2018; Heesakkers et al., 2016).

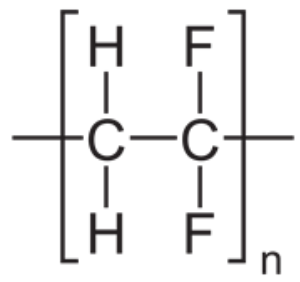

Fig. 3. An illustration of the chemical structure of polyvinylidene difluoride (PVDF).

\subsection{Polycaprolactone (PCL)}

PCL is a biodegradable polymer with several desirable properties (Fig. 4A); it is easily processable as it has a low melting point between 55 and $60^{\circ} \mathrm{C}$ and possess good flexibility due to its low glass transition temperature of $-60^{\circ} \mathrm{C}$. Moreover, PCL has good solubility in many organic solvents such as chloroform, tetrahydrofuran or methylene chloride (Pulkkinen, 2011). PCL is degraded by hydrolysis of its ester linkages in physiological conditions, such as on subdermal implantation (Kumari et al., 2010). The products generated are metabolised via the tricarboxylic acid cycle or are renally eliminated (Escobar Ivirico et al., 2006). 
PCL degrades much slower than other known biodegradable polymers (such as polylactic acid; PLA), ranging from several months to years, but this is dependent on internal factors, such as its molecular weight (Woodruff and Hutmacher, 2010). Degradation time increases as molecular weight increases. For instance, the degradation of a high molecular weight PCL may take from two to four years (Pulkkinen, 2011). This fact makes this polymer very suitable for the manufacture of long-term drug delivery devices. However, if a slow degradation rate is not appropriate for the final application, PCL can be combined with other biodegradable polymers (by copolymerization and blending) in order to increase this degradation rate (Pulkkinen, 2011; Sun et al., 2006).

PCL is suitable for use with HME and fused deposition modelling (FDM) 3D printing technology since its thermal stability allows it to withstand elevated temperatures. The excellent biocompatibility of this material has led to its use as an implantable biomaterial for applications such as tissue engineering scaffolds, sutures and wound dressings (Nair and Laurencin, 2007). Tappa et al. were able to extrude oestrogen and progesterone loaded PCL polymer filaments at $90-100^{\circ} \mathrm{C}$ and successfully used FDM to 3D print oestrogen and progesterone loaded vaginal meshes at $110^{\circ} \mathrm{C}$ (Tappa et al., 2017). Additionally, a variant of PCL modified with ureidopyrimidinone motifs (UPy-PCL) (Fig. 4B) has also been used for the manufacture of surgical meshes due to its elasticity, flexibility, and customisable degradation properties (Felfel et al., 2016; Hympanova et al., 2017). Moreover, Mollet et al. showed that UPy-functionalised polymers had the capacity to combine cell-adhesive peptides to be used for tissue engineering applications (Mollet et al., 2014).
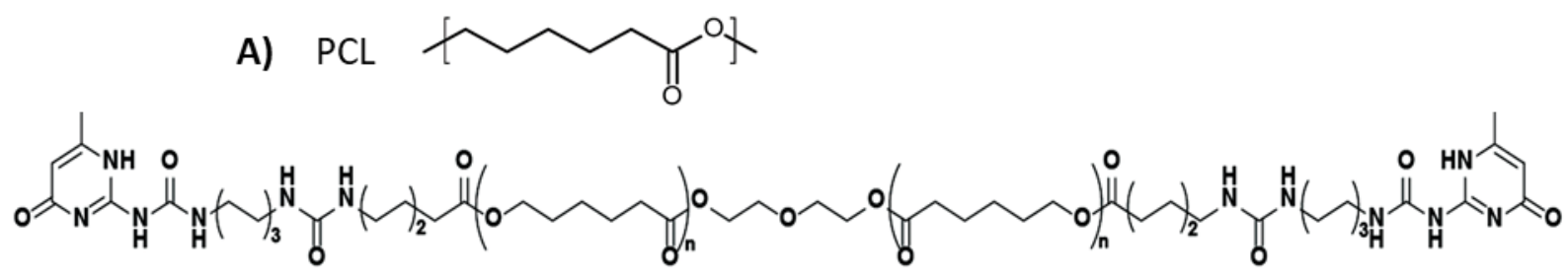

B) $\quad \mathrm{UPy}-\mathrm{PCL}$

Fig. 4. An illustration of the chemical structure of poly(caprolactone) (PCL) (A) and polycaprolactone endfunctionalised with UPy-unit (UPy-PCL) (B), reproduced with permission from the cited reference (Spaans et al., 2017). 


\subsection{Polylactic acid (PLA)}

PLA (Fig. 5) is a biodegradable, bioresorbable and low-cost polymer that can be obtained through the polymerisation of lactic acid obtained from natural resources such as corn starch, rice or potatoes, among others (Nofar et al., 2019; Stewart et al., 2018). PLA shows mechanical properties and processability similar to other synthetic polymers, such as PP, while presenting higher abundance and biodegradability (Mukherjee and Kao, 2011). Lactic acid is mostly present in two optically active forms, D-lactic acid and L-lactic acid. Accordingly, PLA can be made using both types of monomers (Xiao et al., 2012).

The biodegradability of PLA is influenced by the chirality of the monomer. It has been established that L-form degrades lower than D and D/L forms (Stewart et al., 2018). Therefore, although PLLA has been commonly considered an ideal candidate for the manufacture of orthopaedic devices (Nair and Laurencin, 2007), where a long-term structural support is required, D and D/L forms of PLA represent more appropriate candidates for the production of drug delivery vehicles (Nair and Laurencin, 2007). PLA forms undergo hydrolytic degradation via the bulk erosion mechanism by the random cleavage of the ester bond (Grizzi et al., 1995). Eventually, this polymer degrades into lactic acid, which is broken down into water and carbon dioxide via the citric acid cycle (Nair and Laurencin, 2007).

PLA melts between 180 and $220^{\circ} \mathrm{C}$, deeming it suitable for 3D printing (Pawar et al., 2014). Chen et al. shows the preparation of drug delivery systems (DDSs) for the controlled release of diclofenac sodium (an analgesic and anti-inflammatory drug) by HME, proving that PLA is also a suitable material for HME (Chen et al., 2016). PLA is commonly used in biomedical applications such as DDSs, tissue engineering and implantable devices. The wide use of PLA is owed to its biocompatibility, low immunogenicity and non-toxic degradation products (Pawar et al., 2014). A potential drawback of this polymer is its brittle nature; however, this can be overcome by blending PLA with other polymers to improve this property (Saini et al., 2016). Roman et al. demonstrated that PLA scaffolds which were implanted into the abdomen of rabbits, achieved better integration with host tissues compared to PP mesh (Roman et al., 2016). The PP mesh induced a chronic inflammatory 
response in the surrounding tissues, whereas the PLA scaffold showed evidence of

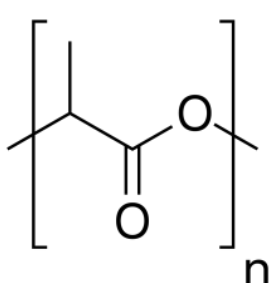

316

Fig. 5. An illustration of the chemical structure of polylactic acid (PLA).

\subsection{Thermoplastic polyurethane (TPU)}

Polyurethanes (PU) are a large group of polymers obtained from the reaction of diisocyanates with polyols using a catalyst, as can be seen in Fig. 6 (Stewart et al., 2018). This type of polymer is capable of producing a large range of structures, each with differing properties due to the ability of using various polyols/diiscyanates to produce this material (Joseph et al., 2018).

For instance, TPU is a polymer, which combines the desirable properties of thermoplastics and rubber, providing easy processability and elasticity. Further advantages of TPU include biocompatibility, flexibility, hemocompatibility and thermal stability (Wang et al., 2019). Haryńska et al. report that TPU can be hot-melt extruded into filaments suitable for use in FDM (Haryńska et al., 2018). These authors also outline that TPU has already been successfully used for applications such as tissue-engineered scaffolds and breast implants. Moreover, a recent study (Juan Domínguez-Robles et al., 2020) combined FDM and HME technology to produce TPU surgical mesh implants focusing on the treatment of PFDs. Lambertz et al. report that hernia meshes with small pores can fill with fibrous tissue in-vivo, reducing mesh flexibility and inducing pain (Lambertz et al., 2015). Current hernia-indicated meshes are inelastic, increasing the likelihood of pore-collapse under mechanical strain. However, it was found that TPU mesh improves elasticity and structural stability, preserving porosity when mechanical strain is applied, which could potentially reduce mesh-related pain in the patient. Furthermore, most grades of TPU are non-biodegradable, making this 
material an ideal candidate for urogynecological meshes since it would provide the longterm structural support required for a successful PF repair.
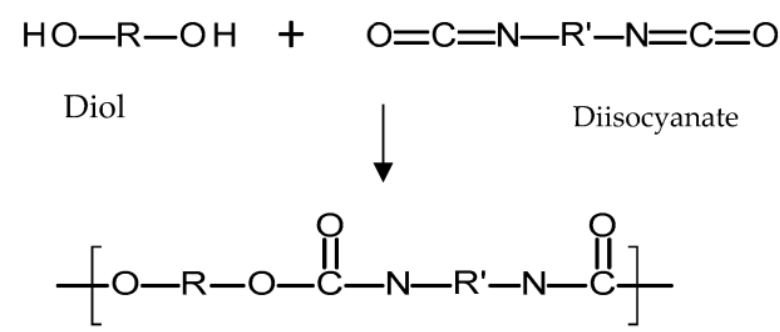

PU

Fig. 6. An Illustration of the chemical structure of polyurethane (PU). Reproduced with permission from the cited reference (Stewart et al., 2018).

\section{Methods of urogynecological surgical mesh manufacture}

A variety of factors including cost, efficiency and differences in properties of the produced implantable devices need to be considered when choosing a manufacturing process. Implantable devices, such as vaginal meshes could be manufactured using a variety of techniques including injection moulding, electrospinning, HME or more recently 3D printing. Moreover, implantable devices that have been manufactured by different methods rarely from polymers with exactly the same structure and, therefore, will degrade at different rates (Fialho and Silva Cunha, 2005). For instance, Fialho et al. compared two different techniques, hot moulding and compression to manufacture intra-ocular implants and found that the process employed considerably influenced the polymer degradation (Fialho and Silva Cunha, 2005).

\subsection{Injection moulding}

Thermoplastic polymers can be manufactured into implantable devices using injection moulding. In this manufacturing process, the polymer is molten, injected into a mould and allowed to solidify (Stewart et al., 2018). One of the main advantages of injection moulding is the ability to scale production in mass. Moreover, injection moulding produces low scrap rates and it is a very repeatable manufacturing technique, which is a great feature when producing brand consistency and part reliability in high volume production. However, up-front costs are very high due to design, testing and expensive equipment. Moreover, since 
the moulds are commonly made out of steel or aluminium, it can restrict the ability to timely implement modifications to the final product. A further limitation of this conventional technique is the incapability of creating geometrically complex objects, which is often a requirement in the medical device industry (Cisneros-López et al., 2019).

\subsection{Electrospinning}

Electrospinning is a simple and effective technique that uses an electrostatic field to generate nanofibers of polymers, metals, ceramics, and composites (Hall Barrientos et al., 2019; Jose Varghese et al., 2019; Long et al., 2019). Electrospun nanofibers present some advantages, including their high surface to volume ratio and very high and tuneable porosity, which produces a large and easily accessible surface (Kenry and Lim, 2017). These are desirable characteristics for applications in fields such as biomedicine and biotechnology (Xue et al., 2017). This technology also allows for the direct functionalisation of nanofibers with active compounds, such as antibiotics and is compatible with different solvents such as chloroform or dimethyl sulfoxide, among others (Hall Barrientos et al., 2017a). For instance, Hall Barrientos et al. made drug-loaded electrospun PCL nanofibers that may potentially be used within a surgical mesh context (Hall Barrientos et al., 2017a). In a different study, Hall Barrientos et al. manufactured drug loaded electrospun PLA-collagen-based nanofibers for potential use in tissue engineering applications (Hall Barrientos et al., 2017b).

Further examples of surgical meshes using the electrospinning process to potentially treat PFDs are found in the literature (Hympanova et al., 2017; Hympánová et al., 2020; Roman et al., 2016). Roman et al. evaluated the host response and biomechanical outcomes of two alternative materials such as PLA and PU to assess their potential for treating PDFs (Roman et al., 2016). The results were compared with two commercially available surgical meshes made from PP (Gynecare ${ }^{\mathrm{TM}}$, Johnson \& Johnson) and PVDF (DynaMesh®). PLA and PU meshes preserved mechanical integrity without sustained inflammation for 90 days after implantation in comparison with the commercial meshes (Roman et al., 2016). In a different study (Hympanova et al., 2017), authors manufactured an electrospun UPy-PCL mesh and evaluated the host response and biomechanical properties of this hybrid material. Moreover, the results were compared with a commercially available surgical mesh made from PP 
391

392

(knitted Restorelle®, Coloplast, Humlebaek, Denmark). Although the UPy-PCL mesh did not compromise physiologic tissue biomechanical properties, it caused a pronounced inflammatory response (Hympanova et al., 2017).

However, electrospun nanofibers commonly include the use of organic solvents, and for biomedical applications such as surgical meshes, it could be a critical issue, as these solvents could pose a health risk to consumers (Agarwal and Greiner, 2011; Bubel et al., 2014). To prevent the use of toxic organic solvents, a process called melt electrospinning (MES) could be used to manufacture these surgical meshes (Brown et al., 2016). For instance, Paul et al. reported that the fabrication of MES PCL meshes for pelvic floor applications promotes an anti-inflammatory responses in mice (Paul et al., 2019). Accordingly, electrospinning polymeric biomaterials has emerged as a promising approach to overcome some of the challenges of commercially available PP transvaginal meshes.

\subsection{Hot-melt extrusion (HME)}

HME is a continuous process, which involves the application of heat and pressure to soften a material, forcing it through an opening to create a product of uniform shape and density (Fig. 7). In the pharmaceutical industry, this process allows for an active pharmaceutical ingredient (API) to be dispersed within a polymer carrier (Stanković et al., 2015). HME is a well-known process that has been increasingly used for a wide range of pharmaceutical and biomedical applications (Baronsky-Probst et al., 2016; Crowley et al., 2007; Domínguez-Robles et al., 2019; J. Domínguez-Robles et al., 2020; Simões et al., 2019). Some advantages of this technology include the ability to improve the solubility of poorly water-soluble compounds and the ability to formulate controlled, extended, sustained and targeted drug delivery systems (Simões et al., 2019). Additionally, Holländer et al. produced intrauterine systems (IUS) from PCL extrudates containing indomethacin (a nonsteroidal anti-inflammatory drug), demonstrating the potential of using HME technology to create patient-specific medical devices (Holländer et al., 2016). Moreover, HME can be used to produce filaments with a uniform diameter which are required for use in FDM 3D printing (Juan Domínguez-Robles et al., 2020; Essyrose Mathew et al., 2019b; Weisman et al., 2015, 2019). 
Tan et al. report that HME can be used to improve the suitability of a material for a specific application, either by blending various polymers or by incorporating a plasticiser (Tan et al., 2018). For example, if a material is deemed too rigid for placement within the human body, a plasticiser could be mixed into the filament to improve mechanical properties such as flexibility. Furthermore, HME in combination with FDM has already been used to 3D print medical devices such as implants (Stewart et al., 2020, 2018), catheters (Essyrose Mathew et al., 2019a, 2019b; Weisman et al., 2019) and surgical meshes (Ballard et al., 2018, 2017; Juan Domínguez-Robles et al., 2020); the latter will be explained in more detail in the following section. One potential drawback of HME is that this thermal process is not suitable for thermolabile polymers or drugs, however, the aforementioned advantages outweigh this disadvantage.

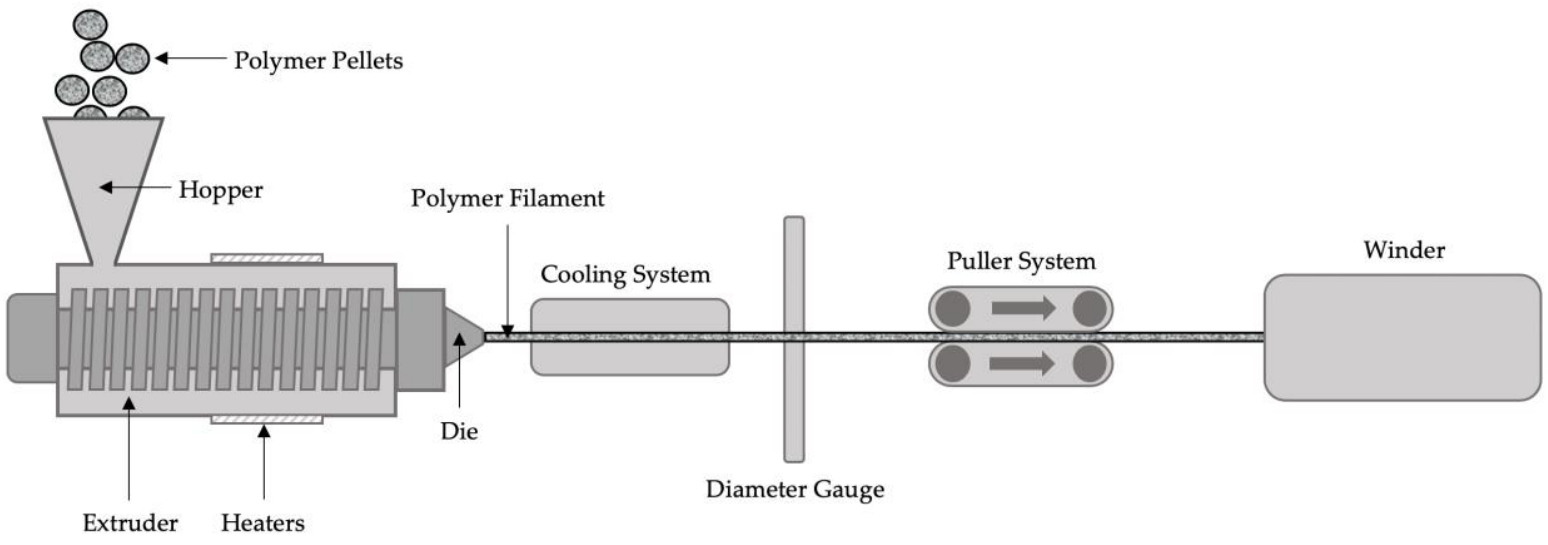

Fig. 7. Schematic diagram of a typical HME system.

\subsection{D printing}

3D printing is an additive manufacturing (AM) technique, which is based on the core concept of successively adding material layer by layer to fabricate a physical threedimensional object (Essyrose Mathew et al., 2019a; Melocchi et al., 2016). With decades of development since its initiation by Charles Hull in the 1980's, 3D printing has become a robust tool for fabricating intricate objects. One rising market for 3D printing is the medical 439 device industry. 3D printing would prove useful for the prototyping and development of new surgical urogynecological meshes (Juan Domínguez-Robles et al., 2020), and indeed 
mesh implants for other applications such as hernia and breast implants (Ahangar et al., 2019;

For any 3D printing process there are common steps which are generally followed: the

444 445 creation of a 3D model using computer-aided design (CAD) software, the use of slicing software to convert the $\mathrm{CAD}$ file into a digital file containing specific instructions for the printer, transferral of the sliced file to the printer, printer set-up and production of the physical object (Fig. 8) (3DPrinting.com, n.d.; Zema et al., 2017). This process enables a representation of the object to be generated prior to its final release, reducing the time and cost associated with product development (Melocchi et al., 2016). If any modifications to the final product are required, this can be quickly and easily achieved by altering the CAD file (Fig. 8) (Ahangar et al., 2019).

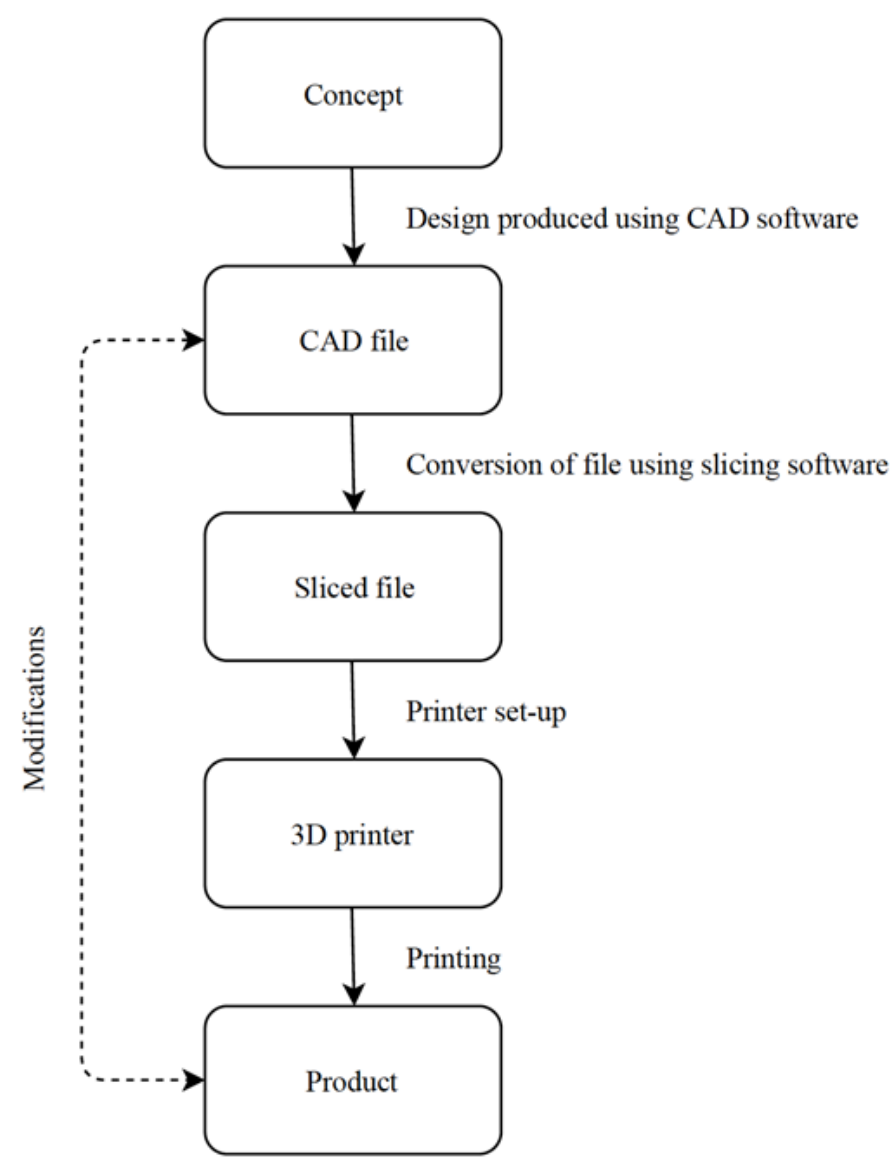

Fig. 8. Outline of the steps generally performed during the 3D printing process.

Within the pharmaceutical and medical device industries, the use of 3D printing technology has grown in response to the movement towards personalised medicine and 
medical devices, as demonstrated by the rapid expansion of literature regarding drug delivery and surgical 3D printing applications (Ballard et al., 2017, 2018; Domínguez-Robles et al., 2019; Juan Domínguez-Robles et al., 2020; Goole and Amighi, 2016; Essyrose Mathew et al., 2019b, 2019a; Stewart et al., 2018, 2020; Tack et al., 2016; Tappa et al., 2017; Weisman et al., 2015, 2019). The future direction of 3D printing will enable a transition away from the current approach of manufacturing large batches of one-size-fits-all medical devices. It is hoped that by using medical imaging it will be possible to create patient-specific devices. 3D modelling could be used to design the medical device based on the patient's anatomical characteristics, and these bespoke devices could then be fabricated at the point of care using a 3D printer (Ahangar et al., 2019).

According to the American Society for Testing Materials (ASTM) there are currently seven various types of 3D printing technologies, including powder bed fusion, material extrusion, material jetting, binder jetting, sheet lamination, direct energy deposition, and vat polymerisation (Fig. 9) (Ahangar et al., 2019; Zhou and Bhaduri, 2019). Among these technologies, FDM, which is a form of material extrusion, is one of the most frequently used in the literature for medical devices and drug delivery system applications due to its ease of use, low cost, wide range of material choice and the ability to fabricate intricate objects. This technique is based upon the extrusion of polymer after it has been softened by heating, deposition of the polymer in successive layers onto a build plate, and cooling of the polymer to ensure the fabricated object retains its shape.

FDM is relatively a low-cost manufacturing technique when compared with other types of AM, simple and flexible. As mentioned in previous sections, it is based on material extrusion. Therefore, a wide variety of thermoplastics can be used to prepare 3D objects using FDM (Essyrose Mathew et al., 2019a; Melocchi et al., 2016). The properties of the resulting object will be dependant not only of the material used, but also on the processing parameters such as the processing temperature, layer height or number of layers (Goh et al., 2020). Accordingly, these parameters need to be optimised before the technique can be used to prepare any type of medical device. 

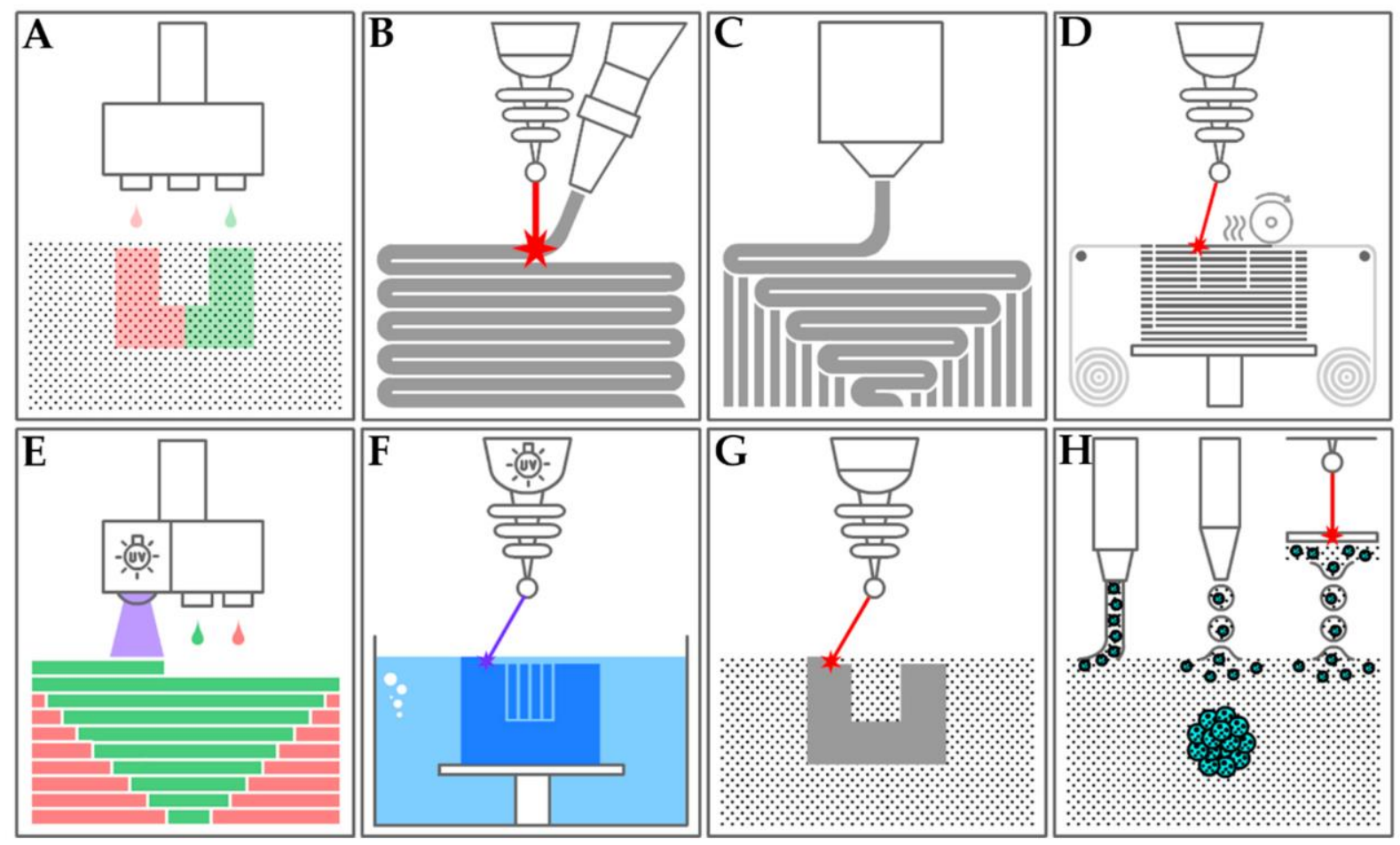

Fig. 9. Types of 3D printing technologies. (A) Binder jetting - this process uses two materials; a build material

(powder form) and a liquid binder, which is acting as an adhesive between powder layers. (B) Directed energy

deposition - this technology consists of a nozzle mounted on a multi axis arm, which deposits melted material onto the specified surface. The material (which typically is a metal) is melted upon deposition with a laser. (C) Material extrusion - materials (thermoplastics) are drawn through a nozzle, where they are heated and then deposited layer by layer on the print bed. (D) Sheet lamination - a sheet of material is cut to size with a blade or laser, the next sheet is bonded in place, over the previous layer, using the adhesive and heat is applied to adhere the layers before the second layer is cut to shape. (E) Material jetting - the material is jetted onto a build platform using either a continuous or Drop on Demand (DOD) approach. The material layers are then usually cured using ultraviolet (UV) light. (F) Vat polymerisation - it uses a vat of liquid photopolymer resin, out of which the model is constructed layer by layer. An ultraviolet (UV) light is then used to cure the resin, whilst the print bed continues to move through the resin one layer at a time. (G) Powder bed fusion - this process uses either a laser or electron beam to melt and fuse material powder together. All different techniques within this process, involve the spreading of the powder material over previous layers.

(H) Extrusion based bioprinting - in this process, which is a variant of the material extrusion, a bioink (biomaterial comprising cells) is extruded from a nozzle or needle layer-by-layer before crosslinking or curing. Reproduced from the open access cited reference (Ahangar et al., 2019). technology for hernia repair or for treating PFDs such as POP can be found in the literature.

504 For instance, Ballard et al. highlight that commercially available prefabricated meshes for 
hernia repair usually require modification to match the specific anatomy of each patient (Ballard et al., 2017). These authors suggest that 3D printing technology could be used to produce patient-specific meshes, based on intraoperative measurements; this could eliminate waste and has the potential to save costs for healthcare systems. They also discuss the potential of using 3D-printed meshes as a depot for local drug delivery. In this particular study, the meshes were 3D-printed using PLA filaments loaded with the antibiotic gentamicin. Promising results were obtained, with a zone of inhibition of $1.1 \pm 0.1 \mathrm{~cm}^{2}$ for $E$. coli and $1.2 \pm 0.1 \mathrm{~cm}^{2}$ for $S$. aureus, compared to no inhibition of bacterial growth when the control meshes without drug were tested. Furthermore, Calero Castro et al. report that the primary complication associated with hernia mesh is bacterial infection of the device (Calero Castro et al., 2019). Therefore, these authors also investigated the effect of using gentamicinloaded filament for 3D printing of hernia meshes. The results from this study were also promising, with an inhibition area of $5.65 \pm 0.46 \mathrm{~cm}^{2}$ for $E$. coli in the presence of meshes containing the antibiotic, compared to the absence of an inhibition zone when no gentamicin was present in the PCL meshes. Moreover, in a recent study (Juan Domínguez-Robles et al., 2020) from our group, HME and FDM technologies were combined in order to produce vaginal meshes loaded with levofloxacin (an antibacterial agent commonly used to treat urinary tract infections) for POP and SUI repair. The meshes were tested for antimicrobial effect on bacterial cultures of E. coli and S. aureus since theses bacterial strains are commonly involved in many community-acquired and nosocomial infections. The diameter of the zone of inhibition in the S. aureus plates with TPU meshes containing levofloxacin ranged from $25.5 \pm 1.4 \mathrm{~mm}$ to $28.6 \pm 0.8 \mathrm{~mm}$, and from $25.2 \pm 0.9 \mathrm{~mm}$ to $28.2 \pm 0.8 \mathrm{~mm}$ in the $E$. coli plates (Juan Domínguez-Robles et al., 2020). In another study (Qamar et al., 2019), 3D printing technology was used to produce hernia meshes loaded with the antibacterial agent ciprofloxacin hydrochloride. The authors performed in vivo testing of these drug-loaded meshes in rabbit models, and it was found that the presence of ciprofloxacin hydrochloride promoted faster wound-healing with no signs of implant rejection. These aforementioned studies highlight the potential of using 3D printing to control the risk of post-operative medical device infection by incorporating antibiotic-loaded filaments, commonly prepared using HME. 
A further proposal would be to load filament with oestradiol in addition to an antibiotic, since oestradiol-releasing mesh is capable of supporting new tissue growth and can promote neovascularisation (Mangir et al., 2019a). For instance, Tappa et al. engineered customisable 3D-printed implants capable of eluting oestrogen or progesterone (Tappa et al., 2017). In addition to intrauterine devices and pessaries, surgical meshes intended for gynaecologic applications were successfully prepared using PCL filament loaded with oestrogen or progesterone. The results from this study indicated extended hormone release was achieved over the period of a week, and even after seven days therapeutic concentrations were measured, leading the authors to conclude that 3D printing is a feasible technique for producing hormone-eluting meshes.

The use of AM for the fabrication of urogynecological surgical mesh is still a novel area of research, however, the studies discussed above demonstrate the potential of using 3D printing as an alternative manufacturing method for patient-specific medical devices. Most of the materials used for urogynecological surgical meshes are thermoplastics. Accordingly, FDM has been the main AM technique used to prepare this type of meshes. Other techniques such as material jetting and stereolithography (Dikshit et al., 2018, 2017; Yang et al., 2020) have the potential to be used for the manufacturing of meshes for such applications. However, in order to be able to use these techniques properly, more research is needed to optimize the procedures and/or the materials used.

Despite all the promising results presented above, AM techniques have some current limitations. The main one is that is a slow technique (Thomas-Seale et al., 2018) when compared with the previously described ones. Therefore, is not an easy to scale up AM production for industrial manufacturing. It can be used to prepare medical devices on demand covering specific patient's needs, but not on a mass production (Thomas-Seale et al., 2018). Moreover, there are some unsolved regulatory questions about the use of 3D printing for medical device manufacturing. However, the FDA is working to towards of solving this. FDA has already released some guidelines describing the appropriate use of this type of technology for the manufacture of medical products (Gottlieb, 2017). 
The following table (Table 1) summarises the materials, manufacturing techniques

564 and drugs (if relevant) used for the manufacture of the different mesh implants and their

565 applications, which have been described in the literature and discussed in previous sections

566 of this manuscript.

567 Table 1. Literature overview of surgical mesh implants and their applications.

\begin{tabular}{|c|c|c|c|c|}
\hline Matrix/Materials & $\begin{array}{c}\text { Manufacturing } \\
\text { technique }\end{array}$ & Drug & Applications & References \\
\hline PCL & Electrospinning & $\begin{array}{l}\text { Levofloxacin, } \\
\text { Irgasan }\end{array}$ & Hernia repair & $\begin{array}{c}\text { (Hall } \\
\text { Barrientos et } \\
\text { al., 2017a) }\end{array}$ \\
\hline TPU & $\begin{array}{l}\text { Fused deposition } \\
\text { modeling }\end{array}$ & Levofloxacin & PFDs & $\begin{array}{l}\text { (Juan } \\
\text { Domínguez- } \\
\text { Robles et al., } \\
\text { 2020) }\end{array}$ \\
\hline PVDF & $\begin{array}{c}\text { Textile } \\
\text { construction }\end{array}$ & $\begin{array}{l}\text { Hydrocortisone, } \\
\text { Aldosterone, } \\
\text { Spironolactone, } \\
\text { Mifepristone }\end{array}$ & Hernia repair & $\begin{array}{l}\text { (Brandt et } \\
\text { al., 2011) }\end{array}$ \\
\hline $\begin{array}{c}\text { PP } \\
(\text { Restorelle®) })^{*}, \\
\mathrm{UPy}^{*} \mathrm{PC}^{* *}, \\
\mathrm{PU}^{* *}\end{array}$ & $\begin{array}{l}\text { Warp knitting*, } \\
\text { Electrospinning** }\end{array}$ & No drugs & PFDs: POP & $\begin{array}{c}\text { (Hympánová } \\
\text { et al., 2020) }\end{array}$ \\
\hline PCL & $\begin{array}{l}\text { Fused deposition } \\
\text { modeling }\end{array}$ & $\begin{array}{c}\text { Estrone (E1), } \\
\text { Estradiol (E2), } \\
\text { Estriol (E3), } \\
\text { Progesterone (P) }\end{array}$ & $\begin{array}{c}\text { Intrauterine } \\
\text { devices }\end{array}$ & $\begin{array}{c}\text { (Tappa et al., } \\
\text { 2017) }\end{array}$ \\
\hline $\begin{array}{c}\text { PP } \\
\left(\text { Restorelle®) }{ }^{*},\right. \\
\text { UPy-PCL }\end{array}$ & $\begin{array}{l}\text { Warp knitting*, } \\
\text { Electrospinning }\end{array}$ & No drugs & PFDs: POP & $\begin{array}{c}\text { (Hympanova } \\
\text { et al., 2017) }\end{array}$ \\
\hline $\begin{array}{l}\text { PLA-PCL } \\
\text { copolymer }\end{array}$ & $\begin{array}{l}\text { Two-photon } \\
\text { polymerization }\end{array}$ & No drugs & $\begin{array}{l}\text { Tissue } \\
\text { engineering } \\
\text { and } \\
\text { regenerative } \\
\text { medicine }\end{array}$ & $\begin{array}{c}\text { (Felfel et al., } \\
\text { 2016) }\end{array}$ \\
\hline $\begin{array}{l}\text { UPy-PCL } \\
\text { UPy-PEG } \\
\text { UPy-RGD } \\
\text { peptide }\end{array}$ & Electrospinning & No drugs & $\begin{array}{l}\text { Bioartificial } \\
\text { kidney } \\
\text { membrane }\end{array}$ & $\begin{array}{c}\text { (Mollet et al., } \\
\text { 2014) }\end{array}$ \\
\hline UPy-PCL & Not specified & $\begin{array}{l}\text { Catechol } \\
\text { additives }\end{array}$ & $\begin{array}{c}\text { Cardiac tissue } \\
\text { engineering }\end{array}$ & $\begin{array}{l}\text { (Spaans et } \\
\text { al., 2017) }\end{array}$ \\
\hline
\end{tabular}




\begin{tabular}{|c|c|c|c|c|}
\hline $\begin{array}{l}\text { PLA, } \\
\text { PU }\end{array}$ & Electrospinning & No drugs & PFDs & $\begin{array}{l}\text { (Roman et } \\
\text { al., 2016) }\end{array}$ \\
\hline $\begin{array}{l}\text { PVDF, } \\
\text { TPU }\end{array}$ & Warp knitting & No drugs & Hernia repair & $\begin{array}{c}\text { (Lambertz et } \\
\text { al., 2015) }\end{array}$ \\
\hline $\begin{array}{l}\text { PLGA } \\
\text { PLA }\end{array}$ & $\begin{array}{l}\text { Compression, } \\
\text { hot molding }\end{array}$ & $\begin{array}{c}\text { Dexamethasone } \\
\text { acetate }\end{array}$ & $\begin{array}{l}\text { Intraocular } \\
\text { implants }\end{array}$ & $\begin{array}{c}\text { (Fialho and } \\
\text { Silva Cunha, } \\
\text { 2005) }\end{array}$ \\
\hline $\begin{array}{l}\text { PCL } \\
\text { PLA }\end{array}$ & Electrospinning & $\begin{array}{l}\text { Levofloxacin, } \\
\text { Irgasan }\end{array}$ & Hernia repair & $\begin{array}{c}\text { (Hall } \\
\text { Barrientos et } \\
\text { al., 2019) }\end{array}$ \\
\hline $\begin{array}{c}\text { PLA } \\
\text { PLA-collagen }\end{array}$ & Electrospinning & $\begin{array}{l}\text { Levofloxacin, } \\
\text { Irgasan }\end{array}$ & $\begin{array}{c}\text { Tissue } \\
\text { engineering }\end{array}$ & $\begin{array}{l}\text { (Hall } \\
\text { Barrientos et } \\
\text { al., 2017b) }\end{array}$ \\
\hline PCL-eMSCs & $\begin{array}{l}\text { Melt } \\
\text { electrospinning }\end{array}$ & No drugs & PFDs: POP & $\begin{array}{c}\text { (Paul et al., } \\
\text { 2019) }\end{array}$ \\
\hline PLA-lignin & $\begin{array}{l}\text { Fused deposition } \\
\text { modeling }\end{array}$ & Curcumin & $\begin{array}{l}\text { Wound } \\
\text { dressing }\end{array}$ & $\begin{array}{c}\text { (Domínguez- } \\
\text { Robles et al., } \\
\text { 2019) }\end{array}$ \\
\hline PLA & $\begin{array}{l}\text { Fused deposition } \\
\text { modeling }\end{array}$ & Gentamicin & Hernia repair & $\begin{array}{c}\text { (Ballard et } \\
\text { al., 2017) }\end{array}$ \\
\hline PCL & $\begin{array}{l}\text { Fused deposition } \\
\text { modeling }\end{array}$ & $\begin{array}{c}\text { Contrast agents: } \\
\text { Barium, } \\
\text { Iodinated } \\
\text { contrast, } \\
\text { Gadolinium- } \\
\text { based contrast } \\
\text { medium }\end{array}$ & Hernia repair & $\begin{array}{l}\text { (Ballard et } \\
\text { al., 2018) }\end{array}$ \\
\hline $\begin{array}{c}\text { PP } \\
\text { PVA }\end{array}$ & $\begin{array}{l}\text { Fused deposition } \\
\text { modeling }\end{array}$ & Ciprofloxacin & Hernia repair & $\begin{array}{l}\text { (Qamar et } \\
\text { al., 2019) }\end{array}$ \\
\hline PCL & $\begin{array}{l}\text { Extrusion based } \\
\text { bioprinting }\end{array}$ & Gentamicin & Hernia repair & $\begin{array}{c}\text { (Calero } \\
\text { Castro et al., } \\
\text { 2019) }\end{array}$ \\
\hline PLA & Electrospinning & Oestradiol & PFDs & $\begin{array}{l}\text { (Mangir et } \\
\text { al., 2019a) }\end{array}$ \\
\hline
\end{tabular}

568 The abbreviations used in this table are the following: polycaprolactone (PCL), thermoplastic polyurethane

569 (TPU), polyvinylidene difluoride (PVDF), polycarbonate modified with ureidopyrimidinone motifs (UPy-PC),

570 polyurethane (PU), polycaprolactone modified with ureidopyrimidinone motifs (UPy-PCL), polyethylene

571 glycol modified with ureidopyrimidinone motifs (UPy-PEG), RGD (Arg-Gly-Asp) peptide modified with

572 ureidopyrimidinone motifs (UPy-RGD peptide), polylactic acid (PLA), poly(lactic-co-glycolic acid) (PLGA),

573 polyvinyl alcohol (PVA), and endometrial mesenchymal stem/stromal cells (eMSCs).

\section{5. Conclusions and future directions}


Given the high incidence of PFDs worldwide and the current ban on transvaginal

mesh, it is apparent that new mesh products will need to be developed for POP and SUI repair. New manufacturing techniques could be employed to allow for production of patient-specific mesh implants and new materials should be trialled which are safer and more efficacious than PP, taking into account the biomechanics of the PF.

The use of 3D printing for pharmaceutical and medical device applications has grown rapidly over the past decade, with approximately 200 3D printed medical devices and one 3D printed prescription drug $\left(\right.$ Spritam $^{\circledR}$ ) receiving FDA approval (U.S. Food and Drug Administration, n.d.). Therefore, 3D printing has been identified as a suitable method for the rapid prototyping and manufacture of patient-matched urogynecological surgical meshes. Furthermore, HME will allow various materials to be prepared into filaments for use in 3D printing by FDM, including the incorporation of APIs for local therapeutic effect in the PF. Among the materials discussed in this review, TPU appears to be the most promising for production of urogynecological surgical mesh implants, due to the biocompatibility, good load bearing capacity, high elasticity and good flexibility of this polymer. In our recent study we showed that these unique properties make TPU a promising solution to circumvent the issues associated with PP mesh (Juan Domínguez-Robles et al., 2020). It is hoped that new mesh constructs will improve the quality of life for women with POP and SUI; however, all new mesh products will need to undergo intense regulatory scrutiny to ensure suitability for placement in the PF.

A future approach for the treatments of these PFDs (POP and SUI) can be the use of another 3D printing technology, such as extrusion based bioprinting or simply bioprinting. This technology offers a manufacturing platform that uses biomaterials as the microenvironment for living cells and growth factors (Ng et al., 2019). These materials are often referred to as bioinks. Therefore, bioprinting is a process that aims to combine engineering principles and life sciences for the fabrication of tissue and organ constructs (Mobaraki et al., 2020). As previously reported, the PF is composed of ligaments, muscles and connective tissue, providing support to the overlaying pelvic organs including the bladder, rectum and uterus. Due to the intense strain, which pregnancy and childbirth place 
on the PF, stretching and potentially tearing the PF muscles and connective tissue may occur in parous women. Furthermore, several other risk factors, such as obesity, previous pelvic reconstructive surgery and connective tissue disorders may contribute to both SUI and POP susceptibility. Accordingly, different bioprinting strategies can be implemented to achieve the repair of this connective tissue, aiming to strengthen the PF and provide additional support to the prolapsed pelvic organs.

In situ bioprinting (also known as a in vivo bioprinting) might also be a step forward in this direction. This challenging and new 3D bioprinting approach allows direct printing of bioinks to create or repair living tissues or organs at a defect site in a clinical setting (Guillemot et al., 2010; Singh et al., 2020), and therefore overcome some of the bioprinting of in vitro 3D scaffolds intrinsic limitations. These limitations include: the establishment of a bioreactor for the replacement with damaged tissue or organ (Murdock and Badylak, 2017; Wang et al., 2015), the implantation of the 3D construct (a fragile structure) in the body, and the shape or morphology of the developed construct, which may differ from the actual defect size due to the limited resolution of the current imaging techniques, such as of computed tomography (CT) and magnetic resonance imaging (MRI) scans (Singh et al., 2020). Although the use of this novel technique is currently considered challenging owing to the lack of skill set required, some previous investigations have already shown the potential of this approach for tissue engineering (Di Bella et al., 2018; Li et al., 2017; Singh et al., 2020).

Funding: This research received no external funding.

Conflicts of Interest: The authors declare no conflict of interest.

\section{References}

3DPrinting.com, n.d. What is 3D Printing? [WWW Document]. URL https://3dprinting.com/what-is-3d-printing/ (accessed 12.22.19).

Abdel-Fattah, M., Familusi, A., Fielding, S., Ford, J., Bhattacharya, S., 2011. Primary and repeat surgical treatment for female pelvic organ prolapse and incontinence in parous women in the UK: A register linkage study. BMJ Open 1, 1-10. https://doi.org/10.1136/bmjopen-2011-000206 
Agarwal, S., Greiner, A., 2011. On the way to clean and safe electrospinning-green electrospinning: emulsion and suspension electrospinning. Polym. Adv. Technol. 22, 372-378. https://doi.org/10.1002/pat.1883

Ahangar, P., Cooke, M.E., Weber, M.H., Rosenzweig, D.H., 2019. Current biomedical applications of 3D printing and additive manufacturing. Appl. Sci. 9. https://doi.org/10.3390/app9081713

Andy, U.U., Harvie, H.S., Ackenbom, M.F., Arya, L.A., 2014. Single versus multi-dose antibiotic prophylaxis for pelvic organ prolapse surgery with graft/mesh. Eur. J. Obstet. Gynecol. Reprod. Biol. 181, 37-40. https://doi.org/10.1016/j.ejogrb.2014.07.016 Ayyaru, S., Dinh, T.T.L., Ahn, Y.-H., 2020. Enhanced antifouling performance of PVDF ultrafiltration membrane by blending zinc oxide with support of graphene oxide nanoparticle. Chemosphere 241, 125068. https://doi.org/10.1016/j.chemosphere.2019.125068

Badiou, W., Lavigne, J.-P., Bousquet, P.-J., O'Callaghan, D., Marès, P., de Tayrac, R., 2011. In vitro and in vivo assessment of silver-coated polypropylene mesh to prevent infection in a rat model. Int. Urogynecol. J. 22, 265-272. https://doi.org/10.1007/s00192-010-1330$\mathrm{y}$

Ballard, D.H., Jammalamadaka, U., Tappa, K., Weisman, J.A., Boyer, C.J., Alexander, J.S., Woodard, P.K., 2018. 3D printing of surgical hernia meshes impregnated with contrast agents: in vitro proof of concept with imaging characteristics on computed tomography. 3D Print. Med. 4, 13. https://doi.org/10.1186/s41205-018-0037-4

Ballard, D.H., Weisman, J.A., Jammalamadaka, U., Tappa, K., Alexander, J.S., Griffen, F.D., 2017. Three-dimensional printing of bioactive hernia meshes: In vitro proof of principle. Surgery 161, 1479-1481. https://doi.org/10.1016/j.surg.2016.08.033

Balsamo, R., Illiano, E., Zucchi, A., Natale, F., Carbone, A., Sio, M. De, Costantini, E., 2018. Sacrocolpopexy with polyvinylidene fluoride mesh for pelvic organ prolapse: Mid term comparative outcomes with polypropylene mesh. Eur. J. Obstet. Gynecol. Reprod. Biol. 220, 74-78. https://doi.org/10.1016/j.ejogrb.2017.11.018

Bang, S.L., Belal, M., 2016. Autologous pubovaginal slings: Back to the future or a lost art? Res. Reports Urol. 8, 11-20. https://doi.org/10.2147/RRU.S96957 
Baronsky-Probst, J., Möltgen, C.-V., Kessler, W., Kessler, R.W., 2016. Process design and control of a twin screw hot melt extrusion for continuous pharmaceutical tamperresistant tablet production. Eur. J. Pharm. Sci. 87, 14-21. https://doi.org/10.1016/j.ejps.2015.09.010

Barski, D., Arndt, C., Gerullis, H., Yang, J., Boros, M., Otto, T., Kolberg, H.-C., 2017. Transvaginal PVDF-mesh for cystocele repair: A cohort study. Int. J. Surg. 39, 249-254. https://doi.org/10.1016/j.ijsu.2017.02.006

BBC News, 2018a. Immediate stop to NHS mesh operations [WWW Document]. URL https://www.bbc.co.uk/news/health-44763673 (accessed 12.19.19).

BBC News, 2018b. Vaginal mesh implants: Australia apologises for "decades of pain" [WWW Document]. URL https://www.bbc.co.uk/news/world-australia-45806324 (accessed 12.19.19).

Brandt, C.J., Kammer, D., Fiebeler, A., Klinge, U., 2011. Beneficial effects of hydrocortisone or spironolactone coating on foreign body response to mesh biomaterial in a mouse model. J. Biomed. Mater. Res. Part A 99A, 335-343. https://doi.org/10.1002/jbm.a.33136

Brown, T.D., Dalton, P.D., Hutmacher, D.W., 2016. Melt electrospinning today: An opportune time for an emerging polymer process. Prog. Polym. Sci. 56, 116-166. https://doi.org/10.1016/j.progpolymsci.2016.01.001

Bubel, K., Grunenberg, D., Vasilyev, G., Zussman, E., Agarwal, S., Greiner, A., 2014. Solvent-Free Aqueous Dispersions of Block Copolyesters for Electrospinning of Biodegradable Nonwoven Mats for Biomedical Applications. Macromol. Mater. Eng. 299, 1445-1454. https://doi.org/10.1002/mame.201400116

Calero Castro, F.J., Yuste, Y., Pereira, S., Garvín, M.D., López García, M.Á., Padillo, F.J., de la Portilla, F., 2019. Proof of concept, design, and manufacture via 3-D printing of a mesh with bactericidal capacity: Behaviour in vitro and in vivo. J. Tissue Eng. Regen. Med. 13, 1955-1964. https://doi.org/10.1002/term.2944

Campoccia, D., Montanaro, L., Speziale, P., Arciola, C.R., 2010. Antibiotic-loaded biomaterials and the risks for the spread of antibiotic resistance following their prophylactic and therapeutic clinical use. Biomaterials 31, 6363-6377.

https://doi.org/10.1016/j.biomaterials.2010.05.005 
692

Chen, R., Li, G., Han, A., Wu, H., Guo, S., 2016. Controlled release of diclofenac sodium from polylactide acid-based solid dispersions prepared by hot-melt extrusion. J. Biomater. Sci. Polym. Ed. 27, 529-543. https://doi.org/10.1080/09205063.2016.1141273

Chilkoti, G., Singh, A., Mohta, M., Saxena, A., 2019. Perioperative "stress dose" of corticosteroid: Pharmacological and clinical perspective. J. Anaesthesiol. Clin. Pharmacol. 35, 147. https://doi.org/10.4103/joacp.JOACP_242_17

Cisneros-López, E.O., Pal, A.K., Rodriguez, A.U., Wu, F., Misra, M., Mielewski, D.F., Kiziltas, A., Mohanty, A.K., 2019. Recycled poly(lactic acid)-based 3D printed sustainable biocomposites: a comparative study with injection molding. Mater. Today Sustain. 100027. https://doi.org/10.1016/j.mtsust.2019.100027

Crowley, M.M., Zhang, F., Repka, M.A., Thumma, S., Upadhye, S.B., Kumar Battu, S., McGinity, J.W., Martin, C., 2007. Pharmaceutical Applications of Hot-Melt Extrusion: Part I. Drug Dev. Ind. Pharm. 33, 909-926. https://doi.org/10.1080/03639040701498759 Di Bella, C., Duchi, S., O'Connell, C.D., Blanchard, R., Augustine, C., Yue, Z., Thompson, F., Richards, C., Beirne, S., Onofrillo, C., Bauquier, S.H., Ryan, S.D., Pivonka, P., Wallace, G.G., Choong, P.F., 2018. In situ handheld three-dimensional bioprinting for cartilage regeneration. J. Tissue Eng. Regen. Med. 12, 611-621. https://doi.org/10.1002/term.2476

Dias, F.G.F., Dias, P.H.G.F., Prudente, A., Riccetto, C., 2015. New strategies to improve results of mesh surgeries for vaginal prolapses repair - an update. Int. braz j urol 41, 623-634. https://doi.org/10.1590/S1677-5538.IBJU.2014.0163

Dieter, A.A., Wilkins, M.F., Wu, J.M., 2015. Epidemiological Trends and Future Care Needs for Pelvic Floor Disorders. Curr. Opin. Obstet. Gynecol. 27, 380-384.

Dikshit, V., Nagalingam, A., Yap, Y., Sing, S., Yeong, W., Wei, J., 2017. Investigation of Quasi-Static Indentation Response of Inkjet Printed Sandwich Structures under Various Indenter Geometries. Materials (Basel). 10, 290. https://doi.org/10.3390/ma10030290

Dikshit, V., Nagalingam, A.P., Yap, Y.L., Sing, S.L., Yeong, W.Y., Wei, J., 2018. Crack monitoring and failure investigation on inkjet printed sandwich structures under quasi-static indentation test. Mater. Des. 137, 140-151. https://doi.org/10.1016/j.matdes.2017.10.014 
Domínguez-Robles, J., Larrañeta, E., Fong, M.L., Martin, N.K., Irwin, N.J., Mutjé, P., Tarrés, Q., Delgado-Aguilar, M., 2020. Lignin/poly(butylene succinate) composites with antioxidant and antibacterial properties for potential biomedical applications. Int. J. Biol. Macromol. 145. https://doi.org/10.1016/j.ijbiomac.2019.12.146

Domínguez-Robles, Juan, Mancinelli, C., Mancuso, E., García-Romero, I., Gilmore, B.F., Casettari, L., Larrañeta, E., Lamprou, D.A., 2020. 3D Printing of Drug-Loaded Thermoplastic Polyurethane Meshes: A Potential Material for Soft Tissue Reinforcement in Vaginal Surgery. Pharmaceutics 12, 63. https://doi.org/10.3390/pharmaceutics12010063

Domínguez-Robles, J., Martin, N.K., Fong, M.L., Stewart, S.A., Irwin, N.J., Rial-Hermida, M.I., Donnelly, R.F., Larrañeta, E., 2019. Antioxidant pla composites containing lignin for 3D printing applications: A potential material for healthcare applications.

Pharmaceutics 11. https://doi.org/10.3390/pharmaceutics11040165

Domínguez-Robles, J., Sánchez, R., Díaz-Carrasco, P., Espinosa, E., García-Domínguez, M.T., Rodríguez, A., 2017. Isolation and characterization of lignins from wheat straw: Application as binder in lithium batteries. Int. J. Biol. Macromol. 104. https://doi.org/10.1016/j.ijbiomac.2017.07.015

Escobar Ivirico, J.L., Salmerón Sánchez, M., Sabater i Serra, R., Meseguer Dueñas, J.M., Gómez Ribelles, J.L., Monleón Pradas, M., 2006. Structure and Properties of Poly( $\varepsilon-$ caprolactone) Networks with Modulated Water Uptake. Macromol. Chem. Phys. 207, 2195-2205. https://doi.org/10.1002/macp.200600399

Ezrin, M., 2013. Pipes and Fittings, in: Plastics Failure Guide. Carl Hanser Verlag GmbH \&amp; Co. KG, München, pp. 541-602. https://doi.org/10.3139/9783446428829.011

Felfel, R.M., Poocza, L., Gimeno-Fabra, M., Milde, T., Hildebrand, G., Ahmed, I., Scotchford, C., Sottile, V., Grant, D.M., Liefeith, K., 2016. In vitro degradation and mechanical properties of PLA-PCL copolymer unit cell scaffolds generated by twophoton polymerization. Biomed. Mater. 11, 015011. https://doi.org/10.1088/17486041/11/1/015011

Fialho, S.L., Silva Cunha, A. da, 2005. Manufacturing Techniques of Biodegradable Implants Intended for Intraocular Application. Drug Deliv. 12, 109-116. 
Goh, G.D., Yap, Y.L., Tan, H.K.J., Sing, S.L., Goh, G.L., Yeong, W.Y., 2020. ProcessStructure-Properties in Polymer Additive Manufacturing via Material Extrusion: A Review. Crit. Rev. Solid State Mater. Sci. 45, 113-133.

https://doi.org/10.1080/10408436.2018.1549977

Goole, J., Amighi, K., 2016. 3D printing in pharmaceutics: A new tool for designing customized drug delivery systems. Int. J. Pharm. 499, 376-394. https://doi.org/10.1016/j.ijpharm.2015.12.071

Gottlieb, S., 2017. Statement by FDA Commissioner Scott Gottlieb, M.D., on FDA ushering in new era of 3D printing of medical products; provides guidance to manufacturers of medical devices [WWW Document]. URL https://www.fda.gov/news-events/pressannouncements/statement-fda-commissioner-scott-gottlieb-md-fda-ushering-new-era3d-printing-medical-products (accessed 3.15.19).

Grizzi, I., Garreau, H., Li, S., Vert, M., 1995. Hydrolytic degradation of devices based on poly(dl-lactic acid) size-dependence. Biomaterials 16, 305-311. https://doi.org/10.1016/0142-9612(95)93258-F

Groleau, C., Morin, S.N., Vautour, L., Amar-Zifkin, A., Bessissow, A., 2018. Perioperative corticosteroid administration: a systematic review and descriptive analysis. Perioper. Med. 7, 10. https://doi.org/10.1186/s13741-018-0092-9

Guillemot, F., Souquet, A., Catros, S., Guillotin, B., Lopez, J., Faucon, M., Pippenger, B., Bareille, R., Rémy, M., Bellance, S., Chabassier, P., Fricain, J.C., Amédée, J., 2010. Highthroughput laser printing of cells and biomaterials for tissue engineering. Acta Biomater. 6, 2494-2500. https://doi.org/10.1016/j.actbio.2009.09.029

Hall Barrientos, I., MacKenzie, G., Wilson, C., Lamprou, D., Coats, P., 2019. Biological Performance of Electrospun Polymer Fibres. Materials (Basel). 12, 363. https://doi.org/10.3390/ma12030363

Hall Barrientos, I.J., Paladino, E., Brozio, S., Passarelli, M.K., Moug, S., Black, R.A., Wilson, C.G., Lamprou, D.A., 2017a. Fabrication and characterisation of drug-loaded electrospun polymeric nanofibers for controlled release in hernia repair. Int. J. Pharm. 517, 329-337. https://doi.org/10.1016/j.ijpharm.2016.12.022 
Hall Barrientos, I.J., Paladino, E., Szabó, P., Brozio, S., Hall, P.J., Oseghale, C.I., Passarelli, M.K., Moug, S.J., Black, R.A., Wilson, C.G., Zelkó, R., Lamprou, D.A., 2017b.

Electrospun collagen-based nanofibres: A sustainable material for improved antibiotic utilisation in tissue engineering applications. Int. J. Pharm. 531, 67-79. https://doi.org/10.1016/j.ijpharm.2017.08.071

Haryńska, A., Gubanska, I., Kucinska-Lipka, J., Janik, H., 2018. Fabrication and characterization of flexible medical-grade TPU filament for Fused Deposition Modeling 3DP technology. Polymers (Basel). 10. https://doi.org/10.3390/polym10121304

Heesakkers, J., Chapple, C., De Ridder, D., Farag, F. (Eds.), 2016. Practical Functional Urology. Springer International Publishing, Cham. https://doi.org/10.1007/978-3-31925430-2

Holländer, J., Genina, N., Jukarainen, H., Khajeheian, M., Rosling, A., Mäkilä, E., Sandler, N., 2016. Three-Dimensional Printed PCL-Based Implantable Prototypes of Medical Devices for Controlled Drug Delivery. J. Pharm. Sci. 105, 2665-2676. https://doi.org/10.1016/j.xphs.2015.12.012

Hu, S., Zeng, S., Li, X., Jiang, J., Yang, W., Chen, Y., Li, M., Zheng, J., 2020. Flexible and high performance of n-type thermoelectric PVDF composite film induced by nickel nanowires. Mater. Des. 188, 108496. https://doi.org/10.1016/j.matdes.2020.108496

Hympanova, L., Mori da Cunha, M.G.M.C., Rynkevic, R., Zündel, M., Gallego, M.R., Vange, J., Callewaert, G., Urbankova, I., Van der Aa, F., Mazza, E., Deprest, J., 2017. Physiologic musculofascial compliance following reinforcement with electrospun polycaprolactone-ureidopyrimidinone mesh in a rat model. J. Mech. Behav. Biomed. Mater. 74, 349-357. https://doi.org/10.1016/j.jmbbm.2017.06.032

Hympánová, L., Rynkevic, R., Román, S., Mori da Cunha, M.G.M.C., Mazza, E., Zündel, M., Urbánková, I., Gallego, M.R., Vange, J., Callewaert, G., Chapple, C., MacNeil, S., Deprest, J., 2020. Assessment of Electrospun and Ultra-lightweight Polypropylene Meshes in the Sheep Model for Vaginal Surgery. Eur. Urol. Focus 6, 190-198. https://doi.org/10.1016/j.euf.2018.07.024

Jose Varghese, R., Sakho, E. hadji M., Parani, S., Thomas, S., Oluwafemi, O.S., Wu, J., 2019. Introduction to nanomaterials: synthesis and applications, in: Nanomaterials for Solar 

8.00003-5

814 Joseph, J., Patel, R.M., Wenham, A., Smith, J.R., 2018. Biomedical applications of polyurethane materials and coatings. Trans. IMF 96, 121-129. https://doi.org/10.1080/00202967.2018.1450209

Kenry, Lim, C.T., 2017. Nanofiber technology: current status and emerging developments. Prog. Polym. Sci. 70, 1-17. https://doi.org/10.1016/j.progpolymsci.2017.03.002

Klinge, U., Klosterhalfen, B., Öttinger, A.P., Junge, K., Schumpelick, V., 2002. PVDF as a new polymer for the construction of surgical meshes. Biomaterials 23, 3487-3493. https://doi.org/10.1016/S0142-9612(02)00070-4

Kumari, A., Yadav, S.K., Yadav, S.C., 2010. Biodegradable polymeric nanoparticles based drug delivery systems. Colloids Surfaces B Biointerfaces 75, 1-18. https://doi.org/10.1016/j.colsurfb.2009.09.001

Lachiewicz, M.P., Moulton, L.J., Jaiyeoba, O., 2015. Pelvic Surgical Site Infections in Gynecologic Surgery. Infect. Dis. Obstet. Gynecol. 2015, 1-8. https://doi.org/10.1155/2015/614950

Lambertz, A., Vogels, R.R.M., Binnebösel, M., Schöb, D.S., Kossel, K., Klinge, U., Neumann, U.P., Klink, C.D., 2015. Elastic mesh with thermoplastic polyurethane filaments preserves effective porosity of textile implants. J. Biomed. Mater. Res. Part A 103, 26542660. https://doi.org/10.1002/jbm.a.35411

Lee, Y.-S., Collins, G., Livingston Arinzeh, T., 2011. Neurite extension of primary neurons on electrospun piezoelectric scaffolds. Acta Biomater. 7, 3877-3886. https://doi.org/10.1016/j.actbio.2011.07.013

Li, L., Yu, F., Shi, J., Shen, S., Teng, H., Yang, J., Wang, X., Jiang, Q., 2017. In situ repair of bone and cartilage defects using 3D scanning and 3D printing. Sci. Rep. 7, 9416. https://doi.org/10.1038/s41598-017-10060-3

Loganathan, J., Fayyad, A., Abdel-Fattah, M., 2019. Continence surgery at the time of pelvic organ prolapse repair: a review of the literature. Obstet. Gynaecol. 21, 21-26. https://doi.org/10.1111/tog.12533

Long, Y.-Z., Yan, X., Wang, X.-X., Zhang, J., Yu, M., 2019. Electrospinning, in: 

https://doi.org/10.1016/B978-0-323-51270-1.00002-9

Macleod, S., Chakraborty, S., 2019. Pharmaceutical and Medical Device Safety: A Study in Public and Private Regulation, in: Civil Justice Systems. Bloomsbury Publishing, pp. 237-245.

Mangera, A., Osman, N.I., Chapple, C.R., 2013. Anatomy of the lower urinary tract. Surg. 31, 319-325. https://doi.org/10.1016/j.mpsur.2013.04.013

Mangir, N., Chapple, C., Macneil, S., 2018. Synthetic Materials Used in the Surgical Treatment of Pelvic Organ Prolapse: Problems of Currently Used Material and Designing the Ideal Material, in: Rizvi, R. (Ed.), Pelvic Floor Disorders. IntechOpen, p. 13. https://doi.org/10.5772/intechopen.76671

Mangir, N., Hillary, C.J., Chapple, C.R., MacNeil, S., 2019a. Oestradiol-releasing Biodegradable Mesh Stimulates Collagen Production and Angiogenesis: An Approach to Improving Biomaterial Integration in Pelvic Floor Repair. Eur. Urol. Focus 5, 280 289. https://doi.org/10.1016/j.euf.2017.05.004

Mangir, N., Roman, S., Chapple, C.R., MacNeil, S., 2019b. Complications related to use of mesh implants in surgical treatment of stress urinary incontinence and pelvic organ prolapse: infection or inflammation? World J. Urol. https://doi.org/10.1007/s00345-01902679-w

Mathew, Essyrose, Domínguez-Robles, J., Larrañeta, E., Lamprou, D.A., 2019a. Fused Deposition Modelling as a Potential Tool for Antimicrobial Dialysis Catheters Manufacturing: New Trends vs. Conventional Approaches. Coatings 9, 515. https://doi.org/10.3390/coatings9080515

Mathew, Essyrose, Domínguez-Robles, J., Stewart, S.A., Mancuso, E., O’Donnell, K., Larraneta, E., Lamprou, D.A., 2019b. Fused Deposition Modelling as an Effective Tool for Anti-Infective Dialysis Catheter Fabrication. ACS Biomater. Sci. Eng. acsbiomaterials.9b01185. https://doi.org/10.1021/acsbiomaterials.9b01185

Melocchi, A., Parietti, F., Maroni, A., Foppoli, A., Gazzaniga, A., Zema, L., 2016. Hot-melt extruded filaments based on pharmaceutical grade polymers for 3D printing by fused deposition modeling. Int. J. Pharm. 509, 255-263. 
Mironska, E., Chapple, C., Macneil, S., 2019. Recent advances in pelvic floor repair. F1000Research 8, 1-10. https://doi.org/10.12688/f1000research.15046.1

Mobaraki, M., Ghaffari, M., Yazdanpanah, A., Luo, Y., Mills, D.K., 2020. Bioinks and bioprinting: A focused review. Bioprinting 18, e00080. https://doi.org/10.1016/j.bprint.2020.e00080

Mollet, B.B., Comellas-Aragonès, M., Spiering, A.J.H., Söntjens, S.H.M., Meijer, E.W., Dankers, P.Y.W., 2014. A modular approach to easily processable supramolecular bilayered scaffolds with tailorable properties. J. Mater. Chem. B 2, 2483-2493. https://doi.org/10.1039/C3TB21516D

Mukherjee, T., Kao, N., 2011. PLA Based Biopolymer Reinforced with Natural Fibre: A Review. J. Polym. Environ. 19, 714-725. https://doi.org/10.1007/s10924-011-0320-6 Murdock, M.H., Badylak, S.F., 2017. Biomaterials-based in situ tissue engineering. Curr. Opin. Biomed. Eng. 1, 4-7. https://doi.org/10.1016/j.cobme.2017.01.001

Nair, L.S., Laurencin, C.T., 2007. Biodegradable polymers as biomaterials. Prog. Polym. Sci. 32, 762-798. https://doi.org/10.1016/j.progpolymsci.2007.05.017

Ng, W.L., Chua, C.K., Shen, Y.-F., 2019. Print Me An Organ! Why We Are Not There Yet. Prog. Polym. Sci. 97, 101145. https://doi.org/10.1016/j.progpolymsci.2019.101145 Nofar, M., Sacligil, D., Carreau, P.J., Kamal, M.R., Heuzey, M.-C., 2019. Poly (lactic acid) blends: Processing, properties and applications. Int. J. Biol. Macromol. 125, 307-360. https://doi.org/10.1016/j.ijbiomac.2018.12.002

Paul, K., Darzi, S., McPhee, G., Del Borgo, M.P., Werkmeister, J.A., Gargett, C.E., Mukherjee, S., 2019. 3D bioprinted endometrial stem cells on melt electrospun poly $\varepsilon$ caprolactone mesh for pelvic floor application promote anti-inflammatory responses in mice. Acta Biomater. 97, 162-176. https://doi.org/10.1016/j.actbio.2019.08.003

Pawar, R.P., Tekale, S.U., Shisodia, S.U., Totre, J.T., Domb, A.J., 2014. Biomedical Applications of Poly(Lactic Acid). Rec. Pat. Regen. Med. 4, 40-51.

Primary Care Women's Health Forum, 2019. What is the cost of pelvic organ prolapse to the NHS? [WWW Document]. URL https://pcwhf.co.uk/news/what-is-the-cost-ofpelvic-organ-prolapse-to-the-nhs/ (accessed 10.15.19). 
Pulkkinen, M., 2011. Modified Poly(e-caprolactone) and Poly(lactic acid) Polymers for Controlled and Targeted Drug Delivery. University of Eastern Finland.

Qamar, N., Abbas, N., Irfan, M., Hussain, A., Arshad, M.S., Latif, S., Mehmood, F., Ghori, M.U., 2019. Personalized 3D printed ciprofloxacin impregnated meshes for the management of hernia. J. Drug Deliv. Sci. Technol. 53, 101164.

https://doi.org/10.1016/j.jddst.2019.101164

Roman, S., Urbánková, I., Callewaert, G., Lesage, F., Hillary, C., Osman, N.I., Chapple, C.R., Deprest, J., MacNeil, S., 2016. Evaluating Alternative Materials for the Treatment of Stress Urinary Incontinence and Pelvic Organ Prolapse: A Comparison of the In Vivo Response to Meshes Implanted in Rabbits. J. Urol. 196, 261-269. https://doi.org/10.1016/j.juro.2016.02.067

Royal College of Obstetricians and Gynaecologists, 2013. Pelvic organ prolapse [WWW Document]. URL https://www.rcog.org.uk/en/patients/patient-leaflets/pelvic-organprolapse/ (accessed 10.15.19).

Saini, P., Arora, M., Kumar, M.N.V.R., 2016. Poly(lactic acid) blends in biomedical applications. Adv. Drug Deliv. Rev. 107, 47-59.

https://doi.org/10.1016/j.addr.2016.06.014

Simões, M.F., Pinto, R.M.A., Simões, S., 2019. Hot-melt extrusion in the pharmaceutical industry: toward filing a new drug application. Drug Discov. Today 24, 1749-1768. https://doi.org/10.1016/j.drudis.2019.05.013

Singh, S., Choudhury, D., Yu, F., Mironov, V., Naing, M.W., 2020. In situ bioprinting Bioprinting from benchside to bedside? Acta Biomater. 101, 14-25. https://doi.org/10.1016/j.actbio.2019.08.045

Soler, M., Verhaeghe, P.J., Stoppa, R., 2001. Polyester (Dacron®) Mesh, in: Bendavid, R., Abrahamson, J., Arregui, M.E., Flament, J.B., Phillips, E.H. (Eds.), Abdominal Wall Hernias: Principles and Management. Springer New York, pp. 266-271. https://doi.org/10.1007/978-1-4419-8574-3_35

Spaans, S., Fransen, P.P.K.H., Ippel, B.D., de Bont, D.F.A., Keizer, H.M., Bax, N.A.M., Bouten, C.V.C., Dankers, P.Y.W., 2017. Supramolecular surface functionalization via catechols for the improvement of cell-material interactions. Biomater. Sci. 5, 1541-1548. 
Stanković, M., Frijlink, H.W., Hinrichs, W.L.J., 2015. Polymeric formulations for drug

release prepared by hot melt extrusion: application and characterization. Drug Discov. Today 20, 812-823. https://doi.org/10.1016/j.drudis.2015.01.012

Stewart, S.A., Domínguez-Robles, J., Donnelly, R.F., Larrañeta, E., 2018. Implantable

Polymeric Drug Delivery Devices: Classification, Manufacture, Materials, and Clinical Applications. Polymers (Basel). 10, 1379. https://doi.org/10.3390/polym10121379

Stewart, S.A., Domínguez-Robles, J., McIlorum, V.J., Mancuso, E., Lamprou, D.A., Donnelly, R.F., Larrañeta, E., 2020. Development of a Biodegradable Subcutaneous Implant for Prolonged Drug Delivery Using 3D Printing. Pharmaceutics 12, 105. https://doi.org/10.3390/pharmaceutics12020105

Sun, H., Mei, L., Song, C., Cui, X., Wang, P., 2006. The in vivo degradation, absorption and excretion of PCL-based implant. Biomaterials 27, 1735-1740. https://doi.org/10.1016/j.biomaterials.2005.09.019

Tack, P., Victor, J., Gemmel, P., Annemans, L., 2016. 3D-printing techniques in a medical setting: A systematic literature review. Biomed. Eng. Online 15, 1-21. https://doi.org/10.1186/s12938-016-0236-4

Tan, D.K., Maniruzzaman, M., Nokhodchi, A., 2018. Advanced pharmaceutical applications of hot-melt extrusion coupled with fused deposition modelling (FDM) 3D printing for personalised drug delivery. Pharmaceutics 10.

https://doi.org/10.3390/pharmaceutics10040203

Tandon, B., Blaker, J.J., Cartmell, S.H., 2018. Piezoelectric materials as stimulatory biomedical materials and scaffolds for bone repair. Acta Biomater. 73, 1-20. https://doi.org/10.1016/j.actbio.2018.04.026

Tappa, K., Jammalamadaka, U., Ballard, D.H., Bruno, T., Israel, M.R., Vemula, H., Meacham, J.M., Mills, D.K., Woodard, P.K., Weisman, J.A., 2017. Medication eluting devices for the field of OBGYN (MEDOBGYN): 3D printed biodegradable hormone eluting constructs, a proof of concept study. PLoS One 12. https://doi.org/10.1371/journal.pone.0182929

The National Health Service, 2017. Surgical Procedures for Treatment of Pelvic Organ 
Prolapse in Women [WWW Document]. URL https://www.england.nhs.uk/wpcontent/uploads/2017/11/pelvic-organ-prolapse-mesh-leaflet-v12.pdf

Thomas-Seale, L.E.J., Kirkman-Brown, J.C., Attallah, M.M., Espino, D.M., Shepherd, D.E.T., 2018. The barriers to the progression of additive manufacture: Perspectives from UK industry. Int. J. Prod. Econ. 198, 104-118. https://doi.org/10.1016/j.ijpe.2018.02.003

Tso, C., Lee, W., Austin-Ketch, T., Winkler, H., Zitkus, B., 2018. Nonsurgical Treatment Options for Women With Pelvic Organ Prolapse. Nurs. Womens. Health 22, 228-239. https://doi.org/10.1016/j.nwh.2018.03.007

U.S. Food and Drug Administration, 2019a. Pelvic Organ Prolapse (POP) [WWW Document]. URL https://www.fda.gov/medical-devices/urogynecologic-surgical-meshimplants/pelvic-organ-prolapse-pop (accessed 10.15.19).

U.S. Food and Drug Administration, 2019b. Stress Urinary Incontinence (SUI) [WWW Document]. URL https://www.fda.gov/medical-devices/urogynecologic-surgical-meshimplants/stress-urinary-incontinence-sui (accessed 10.15.19).

U.S. Food and Drug Administration, 2018. Surgical Mesh for Transvaginal Repair of Pelvic Organ Prolapse in the Anterior Vaginal Compartment [WWW Document]. URL https://www.fda.gov/media/122854/download (accessed 11.10.19).

U.S. Food and Drug Administration, n.d. Urogynecologic Surgical Mesh Implants [WWW Document]. URL https://www.fda.gov/medical-devices/implants-andprosthetics/urogynecologic-surgical-mesh-implants (accessed 12.20.19a).

U.S. Food and Drug Administration, n.d. CDER Researchers Explore the Promise and Potential of 3D Printed Pharmaceuticals [WWW Document]. URL https://www.fda.gov/drugs/news-events-human-drugs/cder-researchers-explorepromise-and-potential-3d-printed-pharmaceuticals (accessed 1.2.20b).

Wang, M., He, J., Liu, Y., Li, M., Li, D., Jin, Z., 2015. The trend towards in vivo bioprinting. Int. J. Bioprinting. https://doi.org/10.18063/IJB.2015.01.001

Wang, Z., Yan, J., Wang, T., Zai, Y., Qiu, L., Wang, Q., 2019. Fabrication and properties of a bio-based biodegradable thermoplastic polyurethane elastomer. Polymers (Basel). 11, 1-13. https://doi.org/10.3390/polym11071121

Weber, M.A., Kleijn, M.H., Langendam, M., Limpens, J., Heineman, M.J., Roovers, J.P., 
2015. Local oestrogen for pelvic floor disorders: A systematic review. PLoS One 10. https://doi.org/10.1371/journal.pone.0136265

Weisman, J.A., Ballard, D.H., Jammalamadaka, U., Tappa, K., Sumerel, J., D'Agostino, H.B., 995 Mills, D.K., Woodard, P.K., 2019. 3D Printed Antibiotic and Chemotherapeutic Eluting Catheters for Potential Use in Interventional Radiology. Acad. Radiol. 26, 270-274. https://doi.org/10.1016/j.acra.2018.03.022

Weisman, J.A., Nicholson, J.C., Tappa, K., Jammalamadaka, U., Wilson, C.G., Mills, D.K., 2015. Antibiotic and chemotherapeutic enhanced three-dimensional printer filaments and constructs for biomedical applications. Int. J. Nanomedicine 10, 357-370. https://doi.org/10.2147/IJN.S74811

Wise, J., 2017. NICE to ban mesh for vaginal wall prolapse. BMJ 359:j5523.

Woodruff, M.A., Hutmacher, D.W., 2010. The return of a forgotten polymerPolycaprolactone in the 21st century. Prog. Polym. Sci. 35, 1217-1256. https://doi.org/10.1016/j.progpolymsci.2010.04.002

Wu, J.M., Hundley, A.F., Fulton, R.G., Myers, E.R., 2009. Forecasting the prevalence of pelvic floor disorders in U.S. women: 2010 to 2050. Obstet. Gynecol. 114, 1278-1283. https://doi.org/10.1097/AOG.0b013e3181c2ce96

Wu, P., Grainger, D.W., 2006. Drug/device combinations for local drug therapies and infection prophylaxis. Biomaterials 27, 2450-2467. https://doi.org/10.1016/j.biomaterials.2005.11.031

Wu, Y.M., Welk, B., 2019. Revisiting current treatment options for stress urinary incontinence and pelvic organ prolapse: A contemporary literature review. Res. Reports Urol. 11, 179-188. https://doi.org/10.2147/RRU.S191555

Xiao, L., Wang, B., Yang, G., Gauthier, M., 2012. Poly(Lactic Acid)-Based Biomaterials: Synthesis, Modification and Applications, in: Ghista, D.N. (Ed.), Biomedical Science, Engineering and Technology. InTech.

Xue, J., Xie, J., Liu, W., Xia, Y., 2017. Electrospun Nanofibers: New Concepts, Materials, and Applications. Acc. Chem. Res. 50, 1976-1987. https://doi.org/10.1021/acs.accounts.7b00218 Yang, W., An, J., Chua, C.K., Zhou, K., 2020. Acoustic absorptions of multifunctional 
polymeric cellular structures based on triply periodic minimal surfaces fabricated by

1023 stereolithography. Virtual Phys. Prototyp. 15, 242-249.

1024 https://doi.org/10.1080/17452759.2020.1740747

1025 Zema, L., Melocchi, A., Maroni, A., Gazzaniga, A., 2017. Three-Dimensional Printing of

1026 Medicinal Products and the Challenge of Personalized Therapy. J. Pharm. Sci. 106,

1027 1697-1705. https://doi.org/10.1016/j.xphs.2017.03.021

1028 Zhou, H., Bhaduri, S.B., 2019. 3D printing in the research and development of medical

1029 devices, in: Yang, L., Bhaduri, S.B., Webster, T.J. (Eds.), Biomaterials in Translational

1030 Medicine, Woodhead Publishing Series in Biomaterials. Elsevier, pp. 269-289.

$1031 \quad$ https://doi.org/10.1016/B978-0-12-813477-1.00012-8

1032 Zwolsman, S., Kastelein, A., Daams, J., Roovers, J.P., Opmeer, B.C., 2019. Heterogeneity of

1033 cost estimates in health economic evaluation research. A systematic review of stress

$1034 \quad$ urinary incontinence studies. Int. Urogynecol. J. 30, 1045-1059.

1035 https://doi.org/10.1007/s00192-018-3814-0

1036 